\title{
Effects of Menu Labeling Policies on Transnational Restaurant Chains to Promote a Healthy Diet: A Scoping Review to Inform Policy and Research
}

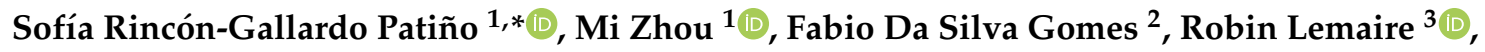 \\ Valisa Hedrick ${ }^{1}$ (D), Elena Serrano ${ }^{1}$ and Vivica I. Kraak ${ }^{1}(\mathbb{D}$ \\ 1 Department of Human Nutrition, Foods, and Exercise, College of Agriculture and Life Sciences, \\ Virginia Polytechnic Institute and State University, Blacksburg, VA 24061, USA; mi14@vt.edu (M.Z.); \\ vhedrick@vt.edu (V.H.); serrano@vt.edu (E.S.); vivica51@vt.edu (V.I.K.) \\ 2 Department of Non-Communicable Diseases and Mental Health, Pan American Health Organization, \\ World Health Organization, Washington, DC 20037, USA; gomesfabio@paho.org \\ 3 Center for Public Administration and Policy, School of Public and International Affairs, Virginia Polytechnic \\ Institute and State University, Blacksburg, VA 24061, USA; rlemaire@vt.edu \\ * Correspondence: sofiargp@vt.edu
}

Received: 30 April 2020; Accepted: 20 May 2020; Published: 26 May 2020

\begin{abstract}
There is insufficient evidence that restaurant menu labeling policies are cost-effective strategies to reduce obesity and diet-related non-communicable diseases (NCDs). Evidence suggests that menu labeling has a modest effect on calories purchased and consumed. No review has been published on the effect of menu labeling policies on transnational restaurant chains globally. This study conducted a two-step scoping review to map and describe the effect of restaurant menu labeling policies on menu reformulation. First, we identified national, state, and municipal menu labeling policies in countries from global databases. Second, we searched four databases (i.e., PubMed, CINHAL/EBSCO, Web of Science, and Google Scholar) for peer-reviewed studies and gray-literature sources in English and Spanish (2000-2020). Step 1 identified three voluntary and eight mandatory menu labeling policies primarily for energy disclosures for 11 upper-middle and high-income countries, but none for low- or middle-income countries. Step 2 identified 15 of 577 studies that met the inclusion criteria. The analysis showed reductions in energy for newly introduced menu items only in the United States. We suggest actions for governments, civil society organizations, and the restaurant businesses to develop, implement, and evaluate comprehensive menu labeling policies to determine whether these may reduce obesity and NCD risks worldwide.
\end{abstract}

Keywords: food labeling; menu labeling; nutrition declaration; food and nutrition policy; restaurant chains; reformulation; serving size; energy; obesity

\section{Introduction}

Unhealthy dietary patterns characterized by the rapid nutrition transition are associated with obesity and diet-related non-communicable diseases (NCDs) [1]. Over the past several decades, dietary patterns have shifted from eating home-cooked meals to eating out more frequently [2,3]. Eating away from home is linked to an increased consumption of ultra-processed food and beverage products with excessive calories, fat, and added sugars and sodium [4-7]. Cafeterias, fast-food restaurant chains, independent take-out-restaurants, and food retailers contribute substantially to the daily energy intake $[8,9]$. A global survey conducted with 30,000 online respondents across 61 countries found that $48 \%$ of participants reported eating away from home weekly or more often with quick-service restaurants (QSRs) and fast-casual restaurants (FCRs) being the most preferred [10]. 
Evidence suggests that food labeling at point-of-purchase may inform shoppers to choose healthier options [11-13]. The World Health Organization (WHO) has recommended nutrition labeling and reducing portion sizes as strategies to reduce energy intake; however, there is insufficient evidence to show that menu labeling legislation for chain restaurants and food retailers is a cost-effective "best buy" policy to improve diet quality and reduce NCD-related disability and mortality in low- and middle-income countries [14].

The aim of menu labeling policies is to reduce energy intake and improve diet quality by helping consumers make better-informed decisions and to encourage food retailers and restaurant businesses to reformulate menu items and reduce and standardize serving sizes to meet recommended nutrient targets $[15,16]$. This dual goal has the potential to improve the nutrition and diet quality of individuals who eat away from home frequently because it may impact entire populations and does not require conscious individual behavior changes [17,18].

The restaurant business sector, which includes QSRs, FCRs, and full-service restaurant (FSR) chains and independent restaurants, has the resources and capacity to reformulate menu items or introduce new items [19-21]. United States (US) chain restaurant establishments have demonstrated progress to improve the nutrition composition of items and reduce meal size or portions served to meet recommended nutrient targets of public health experts, namely, the United States Department of Agriculture and the Dietary Guidelines for Americans [20]. A systematic review conducted in 2019 identified trends for restaurant chains to reformulate food and beverage products and reduce or standardize portions in 30 countries across six regions worldwide between 2000 and 2018 [21]. Recommendations by public health practitioners have been issued to downsize and standardize portions to 600-700 calories or 2510-2930 kilojoules/meal as an important strategy for restaurants to help costumers reduce obesity and NCD risks. However, this research found a lack of clear, universal, and internationally accepted standards for transnational restaurant chains to adopt portion or serving sizes for meals, beverages, side dishes, and desserts served to children, adolescents and adults [21]. The studies reviewed $(n=50)$ also revealed wide variation within and across countries, regions, firms, and restaurant chains to reduce energy, saturated fats, trans fats, sodium, and standardized portions. In addition, menu labeling may influence some of the documented progress [21].

The implementation of menu labeling policies in countries has led to 12 published systematic reviews and/or meta-analyses that examined the influence of restaurant menu labeling on consumer dietary behaviors between 2008 and 2018. These studies documented a modest yet statistical reduction in calories purchased and/or consumed at chain restaurants and other food-service settings [15,22-32]. However, only one published literature review examined the restaurant industry's reformulation of menu items [15]. No review has been published on whether menu labeling policies have an effect on reformulation, introduction of new or existing products, or reduction of serving sizes on menus from transnational restaurant chains globally.

Given the lack of published evidence on this topic, a better understanding is needed of the effects of mandatory and voluntary menu labeling on the restaurant sector's businesses. The results may be used to inform governments, civil society organizations, researchers, and the restaurant sector across countries on whether and how to develop comprehensive and robust policies that encourage industry changes to promote healthy dietary choices that will help to reduce obesity and NCD risks worldwide.

\section{Study Purpose}

The purpose of this study is two-fold: (1) to conduct a scoping review to map and describe the menu labeling policies enacted across countries and regions from 2000 to 2020; and (2) and to examine evaluations for any measurable effects (i.e., positive, no, or mixed) that restaurant menu labeling policies have on businesses to reformulate products or introduce new products and reduce the serving size of menus items served and sold to customers. The results are discussed within the context of government actions needed to strengthen policies and invest in external monitoring and evaluations of menu labeling legislation. We also discuss the need to make a compelling business case 
to encourage restaurant businesses to reformulate menu items to meet recommended healthy nutrient targets. This objective is part of a broader marketing-mix choice-architecture approach to improve their corporate image and attract new customers interested in health and wellness. Finally, we examine the implications for actions for diverse stakeholders, including governments, the WHO, restaurant businesses, private foundations, researchers, and civil society organizations to develop comprehensive menu labeling policies to determine whether these may reduce obesity and NCD risks worldwide.

\section{Materials and Methods}

This study was a two-step scoping review, conducted between 1 January and 29 February 2020 to examine the influence of restaurant menu labeling policies on product reformulation and reducing the serving sizes of menu items across countries and regions globally. This study utilized a scoping review, defined by Sucharew as a "research method and strategy to map, describe, and provide an overview of the published literature to identify relevant data and gaps to inform policymaking and research" [33]. The approach differs from a systematic evidence review that gathers, analyzes, and formally assesses the data to draw robust conclusions from the existing evidence for a well-defined issue.

\subsection{Scoping Review Step 1: Identify Restaurant Menu Labeling Policies}

Step 1 of the scoping review was guided by the following research question: "What restaurant menu labeling policies have been implemented by countries across regions worldwide between January 2000 and February 2020?". The lead investigator (S.R.G.P.) searched the WHO Global database on the Implementation of Nutrition Action (GINA) [34] and the World Cancer Research Fund International's NOURISHING framework [35,36] for national, state, or municipal policies. Then, the data were screened, extracted, compiled and triangulated. The lead investigator used a cross-checked consultation process by reviewing the evidence with other relevant sources (i.e., governmental or health ministry websites and databases, international organizations, and governmental and nongovernmental agency reports) in English and Spanish.

\subsection{Scoping Review-Step 2: Identify Evidence for Restaurant Menu Labeling Effects}

Step 2 of the scoping review step was conducted using the five steps described by Arksey and O'Malley's 2015 framework [37]. To enhance this methodology, we integrated scoping review recommendations by Levac et al. 2010 and Daudt et al. 2012 [38]. The process included identifying the research question, identifying relevant studies that met the inclusion criteria, study selection, charting the data, and summarizing the results. This research followed an iterative approach and used evidence and investigator triangulation to select and analyze the studies.

\subsubsection{Identifying the Research Question}

The development of the research question was guided by the Population, Exposure, Outcome (PEO) framework that is widely used in qualitative social science or policy research rather than the PICO framework (i.e., population, intervention, comparison, and outcome) framework that is used to assess quantitative research outcomes [39-41]. This review defined population as transnational restaurants, including fast-food or QSR, FCR, and FSR chains; exposure was defined as voluntary and/or mandatory menu labeling policies, and the outcomes as food and beverage product reformulation and serving size reduction of restaurant menu items. Step 2 of the scoping review was guided by the following research question was: "What were the effects of voluntary and mandatory restaurant menu labeling policies on food reformulation and serving size available to restaurant consumers between January 2000 and February 2020?" 


\subsubsection{Identifying Relevant Studies}

The initial search was conducted using four electronic databases, including PubMed, CINAHL, Web of Science, and Google Scholar for peer-reviewed literature and gray literature. Only the first 100 hits sorted by relevance were considered for the Google Scholar database search. The databases were selected to be comprehensive and cover a broad range of disciplines, with guidance from a university research librarian. The PEO framework guided the identification of appropriate Medical Subject Headings (MeSH) terms and a combination of synonyms (Table 1; Table S1 provides MeSH terms definitions, and Table S2 provides the search details on each database). The reference sections of relevant articles were handsearched to identify further evidence not captured in the electronic database search.

Table 1. Systematic search strategy for the scoping review.

\begin{tabular}{cc}
\hline PEO Framework & MeSH Terms and Synonyms \\
\hline "Restaurants"[MeSH] OR “Food Services"[MeSH] OR "Food Supply"[MeSH] OR "Fast \\
Foods"[MeSH] OR "Food Industry"[MeSH] OR "Food-Processing Industry"[MeSH] \\
"Chain restaurant" OR restaurant or "food retail" OR “food services" OR "food supply" \\
OR "food supplies" OR "fast food" NOT Schools [MeSH] AND
\end{tabular}

PEO framework: (P) Population—transnational restaurants; (E) Exposure-voluntary and mandatory policies; (O) Outcome-food reformulation and serving size reductions.

\subsubsection{Study Selection}

The evidence selection was based on a priori inclusion and exclusion criteria. This scoping review was limited to peer-reviewed and gray literature published between 1 January 2000 and 29 February 2020 for English and Spanish-language studies and publications that explored the effect of menu labeling for restaurant chains that measured or evaluated the effects of menu labeling on product reformulation and serving size reductions. Studies were excluded for non-restaurant settings including cafeterias, laboratory settings, vending machines, schools, supermarkets, or independent food-retail establishments. Other evidence excluded was based on other outcomes related to consumers, purchase or consumption of nutrients, sales, pricing data, or described prevalence of business compliance. Literature reviews and studies based on packaged food labeling or other marketing strategies were considered to be different interventions and not included. Exclusion criteria also included literature reviews (i.e., scoping reviews, systematic reviews, and meta-analysis), which were removed and classified as the wrong type of study. All citations were imported into an EndNote X9 citation manager system and uploaded to the Covidence software, Cochrane's primary screening and data extraction tool to support scoping and systematic reviews [42]. The screening process used the Preferred Reporting Items for Systematic Reviews and Meta-Analyses (PRISMA; Figure 1) guidelines that enabled the systematic searching, selection, and synthesis of the identified evidence [43]. The primary investigator (S.R.G.P.) removed duplicates, and a co-investigator (M.Z.) independently reviewed the title, abstract, and the full text of studies for inclusion against the eligibility criteria. A third co-investigator (V.I.K.) resolved any disagreements related to study inclusion. 


\subsubsection{Charting the Data}

From each selected study, two investigators (S.R.G.P. and M.Z.) extracted data on the author, year, country, study design, study purpose, sample, setting, data source, main outcomes, and disclosure of conflicts of interest. The data extraction was compiled in a single Microsoft Excel sheet. To assess the study quality, two investigators (S.R.G.P. and M.Z.) used the Johanna Briggs Institute's critical appraisal eight-item checklist for analytical observational studies [44] and assigned a quality score ranging from poor, fair, or good. A third co-investigator (V.I.K.) was consulted to resolve any discrepancies to reach consensus through investigator triangulation.

\subsubsection{Collating, Summarizing and Reporting Results}

We used a narrative synthesis [45] to report and summarize the evidence compiled for restaurant menu labeling policies related to the reformulation and serving size reductions of restaurant menu items, and to compare similarities, differences, and patterns among the evidence. A thematic analysis was also completed during the examination of the studies to identify topics and categorize the main results [46]. We disassembled the evidence to identify relevant themes based on the main outcomes. Thereafter, we reassembled the data across studies and organized it by positive effect if results showed a statistically significant $p$-value, no effect if results showed no statistically significant $p$-value or negative effects, and mixed-effects if results showed both findings for the effects of menu labeling.

\section{Results}

The search identified 3 voluntary and 8 mandatory menu labeling policies in 11 upper-middle and high-income countries defined by The World Bank classification. No policies were identified for low- or middle-income countries. Out of 577 screened studies, 15 studies met the inclusion criteria. Eleven studies were conducted in the Americas region (i.e., Canada and the US), two studies were conducted in the European region (i.e., the UK and Ireland), and two studies were conducted in the Western Pacific region (i.e., Australia) (Table 2).

Table 2. Two-step scoping review results across countries by world region*.

\begin{tabular}{|c|c|c|}
\hline \multirow{2}{*}{ * World Region } & Scoping Review-Step 1 & Scoping Review-Step 2 \\
\hline & Identify Policies (Policies $=11$ ) & Identify Evidence (Studies $n=15$ ) \\
\hline Africa & None identified $(n=0)$ & None identified \\
\hline Americas $(n=2)$ & Canada and US $(n=2)$ & $\begin{array}{l}\text { Canada }(n=1) \text { : Scourboutakos et al. (2019) [47]. US } \\
(n=11) \text { : Bleich et al. (2015) [48], Bleich et al. (2016) } \\
\text { [49], Bleich et al. (2017) [50], Bleich et al. (2018) [19], } \\
\text { Bleich et al. (2020) [51], Bruemmer et al. (2012) [16], } \\
\text { Namba et al. (2013) [52], Petimar et al. (2019) [53], } \\
\text { Saelens et al. (2012) [54], Tran et al. (2019) [55], } \\
\text { Wu et al. (2014) [56] }\end{array}$ \\
\hline South-East Asia & None identified $(n=0)$ & None identified \\
\hline Europe & Ireland and the UK $(n=2)$ & UK $(n=1)$ : Theis et al. (2019) [57] \\
\hline Eastern Mediterranean & $\begin{array}{l}\text { Bahrain, Saudi Arabia, United } \\
\quad \text { Arab Emirates }(n=3)\end{array}$ & None identified \\
\hline Western Pacific & $\begin{array}{c}\text { Australia, Malaysia, South Korea, } \\
\text { Taiwan }(n=4)\end{array}$ & $\begin{array}{l}\text { Australia }(n=2) \text { : Wellard-Cole et al. (2018) [58], } \\
\text { Wellard-Cole et al. (2019) [59]. }\end{array}$ \\
\hline
\end{tabular}

\subsection{Scoping Review Results for Step 1: Identify Restaurant Menu Labeling Policies}

The implementation of voluntary or mandatory menu labeling policies has become popular throughout upper-middle and high-income countries of the world by region including the Americas $n=2$, Europe $n=2$, Eastern Mediterranean $n=3$, Western Pacific $n=4$; including Australia, Bahrain, 
Canada, Ireland, Malaysia, Saudi Arabia, South Korea, Taiwan, United Arab Emirates, the UK and the US (Table 3). No policies were found in the Africa and South-East Asian regions.

We identified eight mandatory menu labeling policies across 11 countries. The US was the first country that enacted a mandatory national menu labeling law in 2010 that became effective on 1 May 2018 [61]. The Food and Drug Administration (FDA) has oversight for implementing the law and provided compliance guidance for industry. Section 4205 of the 2010 Affordable Care Act, Public Law 111-148 (HR 3590) mandated that restaurant chains and other retail establishments (i.e., convenience stores, coffee shops, grocery stores, cafeterias) with 20 or more US locations disclose calories on menus and menu boards and make other nutrition information available to customers upon request [61].

Several countries implemented a mandatory policy at national, state/provincial/territorial levels, including Australia [62], Canada [63], and the United Arab Emirates [64]. Between 2011 and 2018, the Australian government and Obesity Policy Coalition implemented various menu labeling schemes throughout four states and one territory. The current legislative schemes provide detailed requirements for chain food outlets, which include displaying the energy content in kilojoules for items on the menus, drive-through boards, tags, and other materials that display the name or price of products [62].

While mandatory policies have emerged, other countries have launched voluntary recommendations and guidelines to encourage restaurant chains and food industry businesses to display menu labeling for food and beverage items, which include Malaysia in 2008, followed by Bahrain in 2010, and the UK in 2011 [36]. These three countries are moving towards mandatory policies, and initiatives are being debated or incorporated into national plans. In 2016, the Malaysian government included the menu labeling strategy into its National Plan of Action for Nutrition 2016-2025, and plans to have a mandatory menu labeling policy by 2025 [65]. In 2018, Bahrain submitted a proposal to the Ministerial Cabinet that is currently under review for restaurants and cafes to voluntarily display calories [66]. Since 2015, mandatory menu labeling in Ireland has been under consideration and is now included in the National Obesity Policy and Action Plan 2016-2020 [67]. In 2011, the UK government released the voluntary policy for the Out of Home Calorie Labeling pledge as part of The Public Health Responsibility Deal, where businesses voluntarily committed to display the calorie content on menus [68]. The UK government is currently undertaking a consultation to implement menu labeling as a mandatory national policy [69-71].

All the policies across countries require the disclosure of energy content as calories or kilojoules. The US, Australia, and Dubai have mandatory policies that also require the display of daily energy intake statements so a customer can compare specific menu items to 2000 calories/day or 8700 kilojoules/day. Malaysia, Bahrain, and Korea expanded the nutrients that restaurants are required to report to include fat, protein, sodium, and added sugars. Taiwan is the only country that has a mandatory policy that requires the disclosure of caffeine and added sugars for beverages. 
Table 3. Implemented menu labeling policies across countries worldwide, 2008-2020*.

\begin{tabular}{|c|c|c|}
\hline Country, Year & Policy Type & Action \\
\hline Australia, 2011-2018 & $\begin{array}{l}\text { Mandatory, four states and } \\
\text { one territory }\end{array}$ & $\begin{array}{l}\text { Restaurant chains with } \geq 20 \text { outlets in the state, or } 50 \text { or more across the country, are required to present the energy content } \\
\text { (kilojoules) and include a daily intake statement on menus and menu boards. Similar food businesses are invited to voluntarily } \\
\text { implement menu labeling. } \\
\text { States of New South Wales, 2011: Food regulation } 2011 \\
\text { Australia Capital Territory, 2012: Amendments to Food Regulation } 2002 \\
\text { Australia, South Australia, 2012: Amendments to Food Regulation } 2002 \\
\text { Australia, Queensland, 2017: Amendments to Food Act } 2006 \\
\text { Australia, Victoria, 2018: Amendment to Food Act } 1984\end{array}$ \\
\hline Bahrain, 2010 & Voluntary, national & $\begin{array}{l}\text { The Nutrition Section of the Ministry of Health recommends that fast-food chain restaurants display nutrients per serving, } \\
\text { including calories, fat, protein, carbohydrates, salt/sodium, and sugar. }\end{array}$ \\
\hline Canada, Ontario, 2017 & Mandatory, province & $\begin{array}{l}\text { In 2015, Ontario's Healthy Menu Choices Act, part of the Making Healthier Choices Act (Bill } 45 \text { ) in the Ontario Regulation } 50 / 16 \text {, } \\
\text { requires food service establishments with } 20 \text { or more businesses to depict calories for menu items on paper and electronic menus, } \\
\text { menu boards, drive-through menus, menu applications, and advertisements or promotional flyers. }\end{array}$ \\
\hline Ireland, 2015 & Mandatory, national & $\begin{array}{l}\text { In 2015, the Health Service Executive approved the implementation of Calorie Posting Policy across health services in all food and } \\
\text { beverage facilities (i.e., restaurants, coffee shops, catering services, and vending machines). }\end{array}$ \\
\hline Malaysia, 2008 & Voluntary, national & $\begin{array}{l}\text { In 2008, the Malaysian government released voluntary guidelines for the advertising and nutrition labeling of restaurant chains to } \\
\text { display nutrient information on the menu items (i.e., calories, carbohydrates, protein, fat, and sodium for food and total sugar } \\
\text { for beverages). }\end{array}$ \\
\hline Saudi Arabia, 2018 & Mandatory, national & $\begin{array}{l}\text { In 2018, the Saudi Food and Drug Authority launched mandatory measures that require calorie labeling on menu items for all food } \\
\text { facilities, including cashier desks, menu boards, table menus, drive-through menus, phone, and web applications. }\end{array}$ \\
\hline South Korea, 2010 & Mandatory, national & $\begin{array}{l}\text { In 2010, the South Korean government enforced through the Special Act on Safety Control of Children's Dietary Life that } \\
\text { restaurants with more than } 100 \text { outlets are required to report energy, total sugars, protein, saturated fat and sodium on the menus }\end{array}$ \\
\hline Taiwan, 2015 & Mandatory, national & $\begin{array}{l}\text { From 2015, the Taiwanese Act Governing Food Safety and Sanitation that regulates business chains (i.e., convenience stores, drink } \\
\text { vendors, and fast-food restaurants) requires the labeling of the sugar and caffeine content of prepared-when-ordered drinks. }\end{array}$ \\
\hline United Arab Emirates, 2020 & Mandatory, state/emirate & $\begin{array}{l}\text { The 2017-2020 National Nutrition Agenda for Dubai requires food retailers to display the calorie content of menu items and a } \\
\text { daily intake statement, effective } 1 \text { January } 2020 \text {. }\end{array}$ \\
\hline United Kingdom, 2011 & Voluntary, national & $\begin{array}{l}\text { From 2011-2015, the Out of Home Calorie Labelling pledge, part of the government's Responsibility Deal (2010 to 2015), } \\
\text { established for businesses with } 45 \text { or more food establishments the need to provide calorie information on menus in England, } \\
\text { Scotland, and Wales. In 2012, the Food Standards Agency worked with Northern Ireland and the local food industry to encourage } \\
\text { calorie labeling on menus }\end{array}$ \\
\hline United States, 2010-2018 & Mandatory, national & $\begin{array}{l}\text { In 2010, Section } 4205 \text { of the Affordable Care Act, Public Law 111-148 (HR 3590), mandated that restaurant chains and other food } \\
\text { retail establishments (i.e., convenience stores, coffee shops, grocery stores, cafeterias) with } 20 \text { or more locations would be required } \\
\text { to disclose calories and daily intake statements on menus and menu boards and make other nutrition information available to } \\
\text { customers upon request. The law became effective on } 1 \text { May } 2018 .\end{array}$ \\
\hline
\end{tabular}

* Policy is defined as a law, procedure, regulation, rule, or standard that guides how government, businesses, and organizations operate and how citizens live their lives [72]. 


\subsection{Scoping Review Results for Step 2: Identify Evidence for Restaurant Menu Labeling Effects}

The search yielded 560 articles across four electronic databases, and 17 additional records identified manually were included. After removing 58 duplicates, 519 records were screened. Of these, 369 records were excluded by title. Thereafter, 150 records were screened by abstract, 19 selected for full-text assessment, and 15 studies were included in the final scoping review (Figure 1).
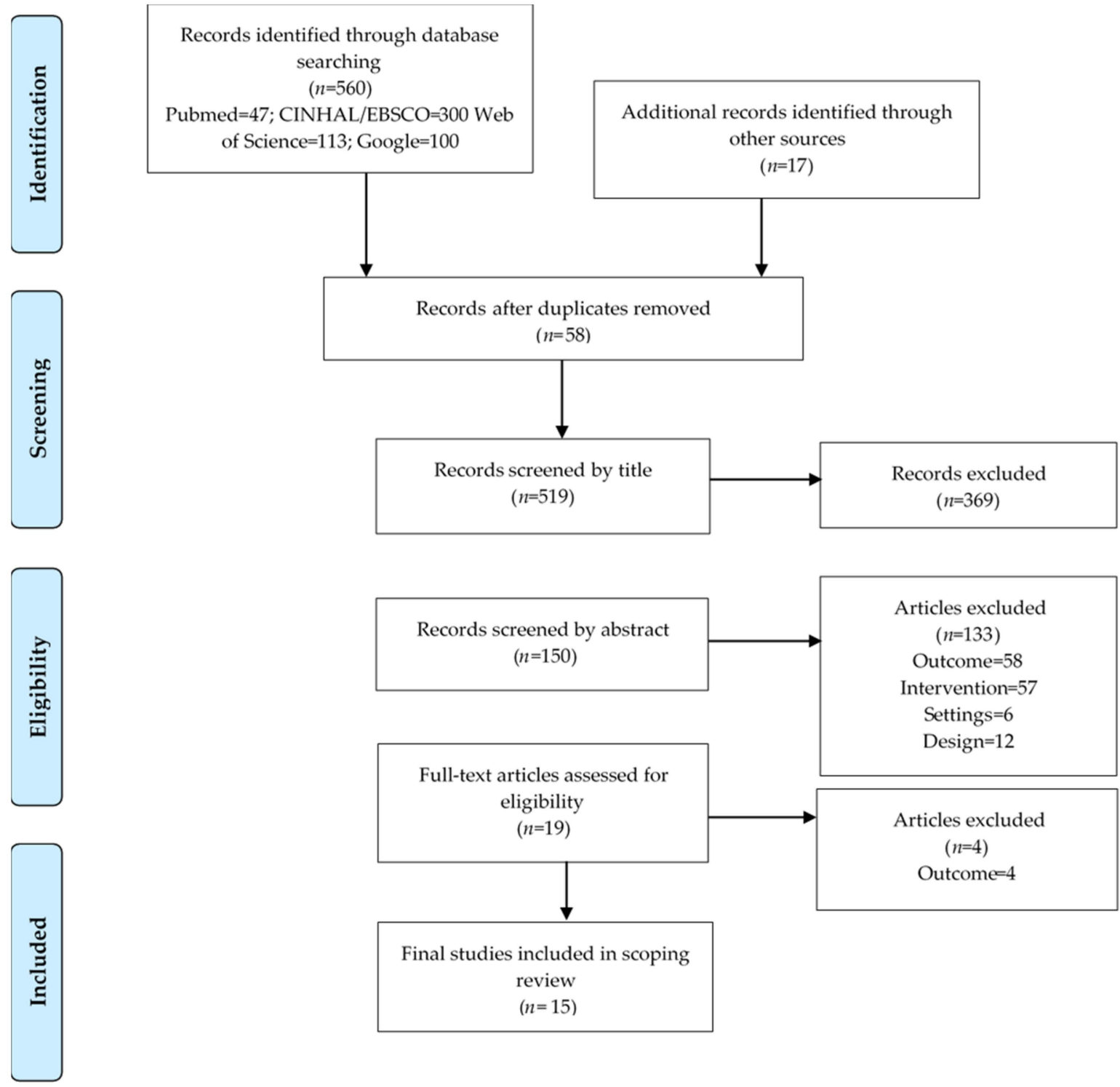

Figure 1. PRISMA flow diagram of the systematic study identification, screening, and selection of the studies for the scoping review.

Table 4 summarizes the studies that met all the inclusion criteria for the scoping review. Despite the search strategy including a wide range of years (from 2000 to 2020), all the included studies were published between 2012 and 2020, and more than half of the studies were published from 2018 to 2020. Eleven studies were conducted in the US, two in Australia, one in Canada, and one in the UK. A majority of studies $(n=14)$ were observational (i.e., longitudinal, case-control, and cross-sectional); and one study was a quasi-experimental design. The analyzed studies $(n=14)$ were conducted in diverse QSR, FCR and FSR chain settings, and a single study included convenience stores [55]. Diverse evidence sources were used across studies to assess the potential effects of menu labeling on food reformulation of food and beverage menu items and the serving reductions. Most of the studies 
used either the MenuStat Database (i.e., a free nutritional database provided by the New York City Department of Health and Mental Hygiene that provides nutritional information on menu items offered by the largest US chain restaurants; $n=7$ ) or consulted business websites, visited establishments, or requested information via email and telephone $(n=7)$ to obtain nutrition content and serving size on menu items offered by restaurants chains. A single study for Canada used the Menu-FLIP database developed by the University of Toronto that provides nutrition data for chain restaurants [73]. The thematic analysis identified three main outcomes: (1) menu items, (2) the nutrition composition of menu items, and (3) newly introduced versus common or regular menu items. No conflicts of interest were found between the studies that could potentially influence the results. Table S3 shows the results of the study quality assessment. No studies were judged as being poor quality, four studies scored fair quality, and 11 studies were considered good quality.

\subsubsection{Changes to Menu Items by Food and Beverage Category}

The classification of menu items across studies varied. Most of the studies included appetizers and side dishes, main courses or entrees, and desserts. Six studies included children's meals $[49,50,52,56,59,74]$ and six studies examined beverages [19,48-50,53,57]. The evidence suggests that most of the changes made by restaurants were for appetizers and side dishes. Four studies showed statistically significant positive effects for calorie reduction $[16,49,50,55]$, and two studies from the UK and the US reported mixed results [52,57].

Positive effects: Tran et al. (2019) conducted a study in the US during the period leading up to the federal menu labeling implementation date of May 2018 and found a reduction on calories mainly in entrees and dropping higher-calorie appetizers, sides, entrees, and desserts from the menus of pizzeria chains [55]. Bleich et al. (2017) described trends in calories from 19,391 US restaurant chain items that found differences in toppings: $93 \mathrm{kcal}$ in 2008 to $84 \mathrm{kcal}$ in 2015 ( $p$-value for trend = 0.001) [50]. Bleich et al. (2016) found that calories declined between 2012 and 2014 for the main course items and children's menu items at QSR, FCR, and FSR chains that suggested restaurants had voluntarily reduced calories in advance of the national menu labeling law [49]. Bruemmer et al. (2012) examined the calorie content of menu items in King County, Washington, and demonstrated statistically significant differences for the calorie content of entrees between 6 and 18 months of the menu labeling county law enactment. These results were presumably due to the reformulation of menu items for selected QSR and independent restaurant chains [16].

Mixed effects: A UK study assessed the effects of a national voluntary menu labeling guidelines for the top 100 UK chain restaurants ranked by sales [57]. Theis and Adams (2019) showed that while there was a reduction of calories and sodium for pizza, sandwiches, and toppings, baked goods items were higher in nutrients of concern (i.e., calories, fat, sugar, and sodium) in restaurants that provided menu labeling for customers [57]. Namba et al. (2013) found evidence that despite the increase in healthier entrees sold by US chain restaurants, a limited improvement was observed for the nutritional content of children's entrees [52]. 
Table 4. Summary of articles included in the scoping review.

\begin{tabular}{|c|c|c|c|c|c|c|c|c|c|c|}
\hline Author Year & Country & Study Design & Purpose & Sample & Setting & $\begin{array}{c}\text { Data } \\
\text { Sources }\end{array}$ & Menu Items & $\begin{array}{c}\text { Nutrition } \\
\text { Composition }\end{array}$ & $\begin{array}{l}\text { New vs. Common } \\
\text { Menu Items }\end{array}$ & Effect * \\
\hline $\begin{array}{l}\text { Bleich et al. } \\
2015 \text { [48] }\end{array}$ & USA & $\begin{array}{l}\text { Observational, } \\
\text { longitudinal }\end{array}$ & $\begin{array}{l}\text { Compare differences } \\
\text { in calorie counts from } \\
\text { menu labeling, } \\
2012-2014\end{array}$ & $\begin{array}{l}23,066 \text { menu items } \\
\text { from } 66\end{array}$ & $\begin{array}{l}\text { Restaurant } \\
\text { chains }\end{array}$ & MenuStat & Food and beverages & $\begin{array}{l}\text { Calories. Average per } \\
\text { item calories } \\
\text { restaurants with } \\
\text { voluntary labeling } \\
\text { was significantly } \\
\text { lower than those } \\
\text { without the labeling } \\
\text { (-286 kcal: } 232 \\
\text { vs. } 519)\end{array}$ & $\begin{array}{l}\text { Lower calorie content } \\
\text { for new menu items } \\
\text { introduced in } 2013 \\
\text { ( }-182 \text { kcal: } 263 \text { vs. } \\
445 ; \text { and in } 2014 \\
(-110 \text { kcal: } 309 \text { vs. } \\
419)\end{array}$ & Positive \\
\hline $\begin{array}{l}\text { Bleich et al. } \\
2016 \text { [49] }\end{array}$ & USA & $\begin{array}{l}\text { Observational, } \\
\text { longitudinal }\end{array}$ & $\begin{array}{l}\text { Describe trends in } \\
\text { calories available in } \\
\text { US chain restaurants } \\
\text { from } 2012 \text { to } 2014 \text { to } \\
\text { better understand } \\
\text { restaurant-driven } \\
\text { changes }\end{array}$ & $\begin{array}{l}23,066 \text { menu } \\
\text { items over } 3 \text { years } \\
\text { in } 66 \text { large chain } \\
\text { restaurants }\end{array}$ & $\begin{array}{l}\text { QSR, FCR } \\
\text { and FSR } \\
\text { chains }\end{array}$ & MenuStat & $\begin{array}{l}\text { Appetizers and sides, } \\
\text { main courses, } \\
\text { desserts, toppings, } \\
\text { beverages, and } \\
\text { children's menu items. } \\
\text { New food, beverages, } \\
\text { and children's menu } \\
\text { items all had fewer } \\
\text { mean calories relative } \\
\text { to old menu items ( } 66, \\
47,43, \text { and } 35 \text { fewer } \\
\text { calories, respectively) }\end{array}$ & $\begin{array}{l}\text { Calories. Predicted } \\
\text { mean per-item } \\
\text { calories in new main } \\
\text { course items in } 2013 \\
\text { had } 85 \text { fewer calories } \\
\text { relative to old main } \\
\text { course items in } 2012 . \\
\text { Calories declined in } \\
\text { pizza (-120 calories), } \\
\text { sandwiches (-82 } \\
\text { calories), and salads } \\
(-68 \text { calories) }\end{array}$ & $\begin{array}{l}\text { Menu items newly } \\
\text { introduced in } 2013 \\
\text { and } 2014 \text { had } \\
\text { significantly fewer } \\
\text { calories relative to } \\
\text { items on the menu in } \\
2012 \text { (2012 vs. } 2013 \text { : } \\
\text {-71 calories; } 2012 \text { vs. } \\
2014,-69 \text { calories) }\end{array}$ & Positive \\
\hline $\begin{array}{l}\text { Bleich et al. } \\
2017 \text { [50] }\end{array}$ & USA & $\begin{array}{l}\text { Observational, } \\
\text { longitudinal }\end{array}$ & $\begin{array}{l}\text { Understand trends in } \\
\text { calories in chain } \\
\text { restaurants before } \\
\text { and after the passage } \\
\text { of the menu labeling } \\
\text { rule }\end{array}$ & $\begin{array}{l}\text { 19,391 menu items } \\
\text { from chain } \\
\text { restaurants }\end{array}$ & $\begin{array}{l}\text { QSR, FCR } \\
\text { and FSR } \\
\text { chains }\end{array}$ & MenuStat & $\begin{array}{l}\text { Appetizers and sides, } \\
\text { fried potatoes, main } \\
\text { courses, toppings, } \\
\text { beverages, and } \\
\text { children's menu items. } \\
\text { Largest differences } \\
\text { were found for } \\
\text { toppings that reduced } \\
\text { from } 93 \mathrm{kcal} \text { in } 2008 \\
\text { to } 84 \mathrm{kcal} \text { in } 2015\end{array}$ & $\begin{array}{c}\text { Calories. Overall } \\
\text { calories declined from } \\
327 \text { kcal in } 2008 \text { to } 318 \\
\text { kcal in } 2015\end{array}$ & - & Positive \\
\hline $\begin{array}{l}\text { Bleich et al. } \\
2018 \text { [19] }\end{array}$ & USA & $\begin{array}{l}\text { Observational, } \\
\text { longitudinal }\end{array}$ & $\begin{array}{l}\text { Compare mean } \\
\text { calories for items that } \\
\text { remained on } \\
\text { restaurant menus } \\
\text { with items dropped } \\
\text { from the menu }\end{array}$ & $\begin{array}{l}27,238 \text { menu items } \\
\text { from restaurant } \\
\text { chains }\end{array}$ & $\begin{array}{l}\text { Restaurant } \\
\text { chains }\end{array}$ & MenuStat & $\begin{array}{l}\text { Appetizers and sides, } \\
\text { main courses, } \\
\text { desserts, and } \\
\text { beverages }\end{array}$ & $\begin{array}{l}\text { Calories. Items that } \\
\text { were dropped had } 71 \\
\text { more calories }\end{array}$ & $\begin{array}{l}\text { Items that stayed on } \\
\text { the menu in all years } \\
\text { had fewer calories } \\
\text { than those items that } \\
\text { were dropped ( } 448 \\
\text { calories vs. } 733 \\
\text { calories) }\end{array}$ & Positive \\
\hline
\end{tabular}


Table 4. Cont.

\begin{tabular}{|c|c|c|c|c|c|c|c|c|c|c|}
\hline Author Year & Country & Study Design & Purpose & Sample & Setting & $\begin{array}{c}\text { Data } \\
\text { Sources }\end{array}$ & Menu Items & $\begin{array}{c}\text { Nutrition } \\
\text { Composition }\end{array}$ & $\begin{array}{l}\text { New vs. Common } \\
\text { Menu Items }\end{array}$ & Effect * \\
\hline $\begin{array}{l}\text { Bleich et al. } \\
2020 \text { [51] }\end{array}$ & USA & $\begin{array}{l}\text { Observational, } \\
\text { longitudinal }\end{array}$ & $\begin{array}{l}\text { Update calorie and } \\
\text { nutrient trends } \\
\text { 2012-2018 of menu } \\
\text { items across } \\
\text { restaurants }\end{array}$ & $\begin{array}{l}28,238 \text { menu items } \\
\text { from chain } \\
\text { restaurants }\end{array}$ & $\begin{array}{l}\text { Fast-food, } \\
\text { fast-casual, } \\
\text { and } \\
\text { full-service } \\
\text { restaurant } \\
\text { chains }\end{array}$ & MenuStat & $\begin{array}{l}\text { Appetizers and sides, } \\
\text { main courses, fried } \\
\text { potatoes, desserts and } \\
\text { baked goods }\end{array}$ & $\begin{array}{c}\text { Calories, saturated fat, } \\
\text { sodium, sugar and } \\
\text { protein.Significant } \\
\text { changes in food } \\
\text { (sugar }-0.67 \mathrm{~g} \text { ) and } \\
\text { beverages } \\
\text { (unsaturated fat } \\
-1.8 \mathrm{~g} \text {, protein }-2.7 \mathrm{~g} \text { ). } \\
\text { Trend in years: } \\
\text { calories }-120 \mathrm{kcals} \\
(-25 \%), \text { saturated fat } \\
-3.4 \mathrm{~g}(-41 \%), \\
\text { unsaturated fat }-4.5 \mathrm{~g} \\
(-37 \%), \text { non-sugar } \\
\text { carbohydrates }-10.3 \mathrm{~g} \\
(-40 \%) \text {, and protein } \\
-4.3 \mathrm{~g}(-25 \%)\end{array}$ & $\begin{array}{l}\text { Significant changes } \\
\text { were found among all } \\
\text { newly introduced } \\
\text { items. It is possible } \\
\text { that the declines in } \\
\text { calories and nutrients } \\
\text { in this study are } \\
\text { related to local or } \\
\text { national nutrition } \\
\text { policies }\end{array}$ & Positive \\
\hline $\begin{array}{c}\text { Bruemmer } \\
\text { et al. } 2012 \\
\text { [16] }\end{array}$ & USA & $\begin{array}{c}\text { Observational, } \\
\text { longitudinal }\end{array}$ & $\begin{array}{c}\text { Evaluated changes in } \\
\text { energy, saturated fat, } \\
\text { and sodium content } \\
\text { of entrees } 6 \text { and } 18 \\
\text { months that occurred } \\
\text { following the } \\
\text { implementation of } \\
\text { menu labeling } \\
\text { regulation }\end{array}$ & 37 chains & $\begin{array}{l}\text { QSR and } \\
\text { FSR chains }\end{array}$ & $\begin{array}{l}\text { Personnel } \\
\text { visited and } \\
\text { recorded } \\
\text { energy } \\
\text { content from } \\
\text { menu labels, } \\
\text { and websites }\end{array}$ & $\begin{array}{l}\text { Entrée items. Calorie } \\
\text { content decline in } \\
\text { overall average entrée } \\
\text { calories ( } 41 \text { fewer } \\
\text { calories post labeling; } \\
73 \text { fewer calories at } \\
\text { full-service } \\
\text { restaurants and } 19 \\
\text { fewer at QSR) when } \\
\text { comparing } 6 \text { and } 18 \\
\text { months post labeling }\end{array}$ & $\begin{array}{l}\text { Calories and sodium. } \\
\text { Decrease in energy, } \\
\text { saturated fat, and } \\
\text { sodium content } \\
\text { between the two } \\
\text { study periods } \\
\text { following } \\
\text { implementation of } \\
\text { menu regulation for } \\
\text { menu items that were } \\
\text { present at both time } \\
\text { periods. Saturated fat } \\
\text { and sodium levels } \\
\text { decreased } \\
\text { significantly across all } \\
\text { chains and SD chains }\end{array}$ & - & Positive \\
\hline
\end{tabular}


Table 4. Cont.

\begin{tabular}{|c|c|c|c|c|c|c|c|c|c|c|}
\hline Author Year & Country & Study Design & Purpose & Sample & Setting & $\begin{array}{c}\text { Data } \\
\text { Sources }\end{array}$ & Menu Items & $\begin{array}{c}\text { Nutrition } \\
\text { Composition }\end{array}$ & $\begin{array}{l}\text { New vs. Common } \\
\text { Menu Items }\end{array}$ & Effect * \\
\hline $\begin{array}{l}\text { Namba et al. } \\
2013 \text { [52] }\end{array}$ & USA & $\begin{array}{l}\text { Observational, } \\
\text { case-control }\end{array}$ & $\begin{array}{l}\text { Evaluate the effect of } \\
\text { menu labeling on } \\
\text { menu offerings over } 7 \\
\text { years, from } 2005 \\
\text { through } 2011\end{array}$ & $\begin{array}{l}3887 \text { menu items } \\
\text { from chain } \\
\text { restaurants }\end{array}$ & $\begin{array}{l}\text { Top } 50 \text { QSR } \\
\text { chains }\end{array}$ & $\begin{array}{l}\text { Restaurant } \\
\text { websites }\end{array}$ & $\begin{array}{l}\text { Entrées, sides, and } \\
\text { children's entrées. } \\
\text { Case restaurants } \\
\text { increased the } \\
\text { proportion of } \\
\text { healthier entrées after } \\
\text { labeling regulations: } \\
\text { from } 13 \% \text { during } \\
\text { years } 2005 \text { through } \\
2008 \text {, up to } 20 \% \text { by } \\
2011 \text { with a mean } \\
\text { difference of } 5 \% \\
\text { pre-post } 2008 \text { in cases } \\
\text { relative to controls. } \\
\text { The prevalence of } \\
\text { healthier side dishes } \\
\text { was higher among } \\
\text { case restaurants than } \\
\text { controls (23\% vs. 15\%, } \\
\text { respectively). } \\
\text { Healthier children's } \\
\text { entrées at case } \\
\text { restaurants were } \\
\text { higher }\end{array}$ & $\begin{array}{l}\text { Calories. Regression } \\
\text { models found no } \\
\text { statistically significant } \\
\text { changes over time in } \\
\text { nutrient averages and } \\
\text { no statistically } \\
\text { significant differences } \\
\text { between the } \\
\text { nutritional averages } \\
\text { of case and control } \\
\text { restaurants }\end{array}$ & $\begin{array}{c}3 \text { of } 5 \text { labeled } \\
\text { restaurants improved } \\
\text { their offerings. } \\
\text { Control restaurants } \\
\text { had a lower } \\
\text { proportion of } \\
\text { healthier items than } \\
\text { cases. } 2 \text { of } 5 \text { showed } \\
\text { no improvement and } \\
\text { even launched new } \\
\text { options, that } \\
\text { increased average } \\
\text { calories by over } 20 \% \\
\text { and cholesterol by } \\
\text { almost } 140 \%\end{array}$ & Mixed \\
\hline $\begin{array}{l}\text { Petimar et al. } \\
2019 \text { [53] }\end{array}$ & USA & $\begin{array}{l}\text { Observational, } \\
\text { longitudinal }\end{array}$ & $\begin{array}{l}\text { Evaluate calorie } \\
\text { labeling in mean } \\
\text { calories purchased, } \\
\text { pre-2015-2017 and } \\
\text { post menu labeling } \\
\text { implementation } \\
\text { period 2017-2018 }\end{array}$ & 59 restaurants & Restaurants & Menustat & $\begin{array}{l}\text { Entrées, sides, } \\
\text { sugar-sweetened } \\
\text { beverages }\end{array}$ & $\begin{array}{l}\text { Calories. The top } 50 \\
\text { menu offerings } \\
\text { purchased in } 2017-18 \\
\text { had a median of } 350 \\
\text { calories (interquartile } \\
\text { range } 440-760 \text { ) } \\
\text { pre-implementation } \\
\text { and a median of } 340 \\
\text { calories (440-760) } \\
\text { post-implementation. }\end{array}$ & - & Positive \\
\hline
\end{tabular}


Table 4. Cont

\begin{tabular}{|c|c|c|c|c|c|c|c|c|c|c|}
\hline Author Year & Country & Study Design & Purpose & Sample & Setting & $\begin{array}{c}\text { Data } \\
\text { Sources }\end{array}$ & Menu Items & $\begin{array}{l}\text { Nutrition } \\
\text { Composition }\end{array}$ & $\begin{array}{l}\text { New vs. Common } \\
\text { Menu Items }\end{array}$ & Effect * \\
\hline $\begin{array}{l}\text { Saelens et al. } \\
2012 \text { [54] }\end{array}$ & USA & $\begin{array}{c}\text { Experimental, } \\
\text { quasi-experimental }\end{array}$ & $\begin{array}{l}\text { Examine changes in } \\
\text { restaurants from } \\
\text { before to after } \\
\text { nutrition-labeling } \\
\text { regulation in a } \\
\text { regulated versus a } \\
\text { nonregulated county } \\
\text { of Washington state }\end{array}$ & Top 10 QSR chains & $\begin{array}{l}\text { QSR and } \\
\text { independent } \\
\text { restaurant } \\
\text { chains }\end{array}$ & $\begin{array}{l}\text { Nutrition } \\
\text { Environment } \\
\text { Measures } \\
\text { Survey } \\
\text { Restaurant } \\
\text { (NEMS-R) }\end{array}$ & $\begin{array}{l}\text { Healthy vs. } \\
\text { Unhealthy based on } \\
10 \text { items examined by } \\
\text { the Nutrition } \\
\text { Environment } \\
\text { Measures } \\
\text { Surveys-Restaurant } \\
\text { version (NEMS-R) }\end{array}$ & $\begin{array}{l}\text { The healthfulness of } \\
\text { children's menus } \\
\text { improved modestly } \\
\text { over time, but not } \\
\text { differentially by } \\
\text { county. Availability of } \\
\text { reduced portions } \\
\text { decreased in the } \\
\text { regulated county }\end{array}$ & - & No effect \\
\hline $\begin{array}{c}\text { Scourboutakos } \\
\text { et al. } 2019 \\
{[47]}\end{array}$ & Canada & $\begin{array}{l}\text { Observational, } \\
\text { longitudinal }\end{array}$ & $\begin{array}{l}\text { Investigate the early } \\
\text { impact of Canada's } \\
\text { mandatory menu } \\
\text { labeling legislation on } \\
\text { calorie levels in foods } \\
\text { offered on chain } \\
\text { restaurant menus } \\
\text { before, leading up to, } \\
\text { and at the } \\
\text { point-of-implementation, } \\
2010 \text { - } 2017\end{array}$ & $\begin{array}{l}2988 \text { foods sold by } \\
28 \text { restaurant } \\
\text { chains }\end{array}$ & $\begin{array}{l}\text { QSR and } \\
\text { FSR chains }\end{array}$ & $\begin{array}{l}\text { Menu-FLIP } \\
\text { database }\end{array}$ & $\begin{array}{c}\text { Entrées, pizza, } \\
\text { breakfast foods, side } \\
\text { dishes, baked } \\
\text { goods/desserts, kids' } \\
\text { foods }\end{array}$ & $\begin{array}{l}\text { Calories. The average } \\
\text { calories per serving } \\
\text { on restaurant menus } \\
\text { increased from } 306 \\
(\mathrm{SD}=6) \mathrm{kcal} \text { to } 346 \\
(\mathrm{SD}=6) \mathrm{kcal}, \text { between } \\
2010 \text { and } 2017 \text {. An } \\
\text { increase in serving } \\
\text { size, from } 155(\mathrm{SD}=3) \\
\text { to } 172(\mathrm{SD}=3) \text { grams, } \\
\text { between } 2010 \text { and } \\
\text { 2017. Calorie density } \\
\text { (kcal per } 100 \mathrm{~g}) \text { did } \\
\text { not significantly differ } \\
\text { between } 2010 \text { and } \\
\text { 2017. Significant } \\
\text { increase in serving } \\
\text { sizes among sit-down } \\
\text { restaurants of } 12 \mathrm{~g} \text { per } \\
\text { serving between } 2010 \\
\text { and } 2017\end{array}$ & $\begin{array}{l}\text { Overall, new foods } \\
\text { introduced in } 2017 \\
\text { were significantly } \\
\text { higher in calories per } \\
\text { serving compared } \\
\text { with those introduced } \\
\text { in 2016. New foods } \\
\text { introduced in } 2017 \\
\text { had significantly } \\
\text { higher serving sizes } \\
\text { compared with new } \\
\text { foods in } 2013 \text { and } \\
2016\end{array}$ & No effect \\
\hline
\end{tabular}


Table 4. Cont.

\begin{tabular}{|c|c|c|c|c|c|c|c|c|c|c|}
\hline Author Year & Country & Study Design & Purpose & Sample & Setting & $\begin{array}{c}\text { Data } \\
\text { Sources }\end{array}$ & Menu Items & $\begin{array}{c}\text { Nutrition } \\
\text { Composition }\end{array}$ & $\begin{array}{l}\text { New vs. Common } \\
\text { Menu Items }\end{array}$ & Effect * \\
\hline $\begin{array}{l}\text { Theis et al. } \\
2019 \text { [57] }\end{array}$ & UK & $\begin{array}{l}\text { Observational, } \\
\text { cross-sectional }\end{array}$ & $\begin{array}{l}\text { Determine whether } \\
\text { there are differences } \\
\text { in the energy and } \\
\text { nutritional content of } \\
\text { menu items served by } \\
\text { UK restaurants vs. } \\
\text { without voluntary } \\
\text { menu labeling }\end{array}$ & $\begin{array}{l}100 \text { UK chain } \\
\text { restaurants }\end{array}$ & $\begin{array}{l}\text { QSR and } \\
\text { FSR chains } \\
\text { ranked by } \\
\text { sales }\end{array}$ & $\begin{array}{l}\text { Restaurant } \\
\text { websites }\end{array}$ & $\begin{array}{l}\text { Appetizers and sides, } \\
\text { baked goods, } \\
\text { beverages, burgers, } \\
\text { desserts, fried } \\
\text { potatoes, mains, } \\
\text { pizza, salads, } \\
\text { sandwiches, soup, } \\
\text { toppings, and } \\
\text { ingredients. Main } \\
\text { dishes (i.e., pizza and } \\
\text { sandwich) had less } \\
\text { sugar and salt. } \\
\text { Toppings and } \\
\text { ingredients had less } \\
\text { fat and protein than } \\
\text { items from } \\
\text { restaurants without } \\
\text { menu labeling. Baked } \\
\text { goods items from } \\
\text { restaurants with } \\
\text { menu labeling had, } \\
\text { more energy, fat, } \\
\text { saturated fat, sugar } \\
\text { but protein and more } \\
\text { salt }\end{array}$ & $\begin{array}{l}\text { Calories, saturated fat, } \\
\text { sodium, sugar, } \\
\text { carbohydrates, and } \\
\text { protein. Restaurants } \\
\text { with menu labeling } \\
\text { had } 45 \% \text { less fat (beta } \\
\text { coefficient } 0.55 ; 95 \% \\
\text { CI } 0.32 \text { to } 0.96 \text { ) and } \\
60 \% \text { less salt (beta } \\
\text { coefficient } 0.40 \text {; } 95 \% \\
\text { CI } 0.18 \text { to } 0.92 \text { ) }\end{array}$ & - & Mixed \\
\hline $\begin{array}{l}\text { Tran et al. } \\
2019 \text { [55] }\end{array}$ & USA & $\begin{array}{l}\text { Observational, } \\
\text { longitudinal }\end{array}$ & $\begin{array}{l}\text { Describe trends in } \\
\text { calories among food } \\
\text { items sold in US } \\
\text { convenience stores } \\
\text { and pizza restaurant } \\
\text { chains from } 2013 \text { to } \\
2017\end{array}$ & $\begin{array}{l}1522 \text { food items } \\
\text { from convenience } \\
\text { stores and } 2085 \\
\text { items from pizza } \\
\text { restaurant chains }\end{array}$ & $\begin{array}{l}\text { Pizza } \\
\text { restaurant } \\
\text { chains }\end{array}$ & MenuStat & $\begin{array}{l}\text { Appetizers and sides, } \\
\text { main courses, and } \\
\text { desserts. Lower } \\
\text { calories among items } \\
\text { that stayed on the } \\
\text { menu compared to } \\
\text { items dropped } \\
\text { (overall: }-60 \text { kcal; } \\
\text { appetizers and sides: } \\
\text {-200 kcal } p<0.001 ; \\
\text { main courses: } \\
\text {-50 kcal } p=0.03 \text {; } \\
\text { desserts }-60 \text { kcal) }\end{array}$ & $\begin{array}{l}\text { Calories. Reduced } \\
\text { calories in menu } \\
\text { items (-56 kcal: } \\
390 \mathrm{kcal} \text { in } 2013 \mathrm{vs.} \\
334 \mathrm{kcal} \text { in } 2017), \\
\text { appetizers (-230 kcal: } \\
367 \mathrm{kcal} \text { in } 2013 \mathrm{vs.} \\
137 \mathrm{kcal} \text { in } 2017)\end{array}$ & $\begin{array}{c}\text { Calories were lower } \\
\text { among items that } \\
\text { stayed on the menu } \\
\text { compared to items } \\
\text { dropped. } \\
\text { Lower-calorie pizza } \\
\text { options were } \\
\text { introduced, but no } \\
\text { significant changes }\end{array}$ & Positive \\
\hline
\end{tabular}


Table 4. Cont

\begin{tabular}{|c|c|c|c|c|c|c|c|c|c|c|}
\hline Author Year & Country & Study Design & Purpose & Sample & Setting & $\begin{array}{c}\text { Data } \\
\text { Sources }\end{array}$ & Menu Items & $\begin{array}{c}\text { Nutrition } \\
\text { Composition }\end{array}$ & $\begin{array}{l}\text { New vs. Common } \\
\text { Menu Items }\end{array}$ & Effect * \\
\hline $\begin{array}{l}\text { Wellard-Cole } \\
\text { et al. } 2018 \\
\text { [58] }\end{array}$ & Australia & $\begin{array}{l}\text { Observational, } \\
\text { longitudinal }\end{array}$ & $\begin{array}{l}\text { Examine the energy } \\
\text { content of Australian } \\
\text { fast-food menu items } \\
\text { before and after menu } \\
\text { board labeling }\end{array}$ & $\begin{array}{l}522 \text { menu items } \\
\text { from fast-food } \\
\text { chains }\end{array}$ & $\begin{array}{l}5 \text { of the } \\
\text { largest } \\
\text { Australian } \\
\text { QSR chains }\end{array}$ & $\begin{array}{l}\text { Fast-food } \\
\text { websites }\end{array}$ & $\begin{array}{c}\text { Breakfast, burgers, } \\
\text { desserts, chicken and } \\
\text { seafood, salads, sides, } \\
\text { sandwiches and } \\
\text { wraps }\end{array}$ & $\begin{array}{c}\text { Calories. No } \\
\text { differences in energy } \\
\text { per serving items, } \\
\text { content per } 100 \mathrm{~g} \text { for } \\
\text { burgers was higher } \\
\text { after implementation } \\
(1040 \mathrm{vs} .999 \mathrm{~kJ} / 100 \mathrm{~g} \\
\text { before } \\
\text { implementation,) }\end{array}$ & & No effect \\
\hline $\begin{array}{l}\text { Wellard-Cole } \\
\text { et al. } 2019 \\
\text { [59] }\end{array}$ & Australia & $\begin{array}{l}\text { Observational, } \\
\text { longitudinal }\end{array}$ & $\begin{array}{l}\text { Investigate the } \\
\text { nutrient composition } \\
\text { of children's meals } \\
\text { offers at fast-food } \\
\text { chains, compare with } \\
\text { children's daily } \\
\text { requirements and } \\
\text { recommendations } \\
\text { and determine if } \\
\text { results have changed } \\
\text { prior to the } \\
\text { implementation of } \\
\text { menu labeling }\end{array}$ & $\begin{array}{l}289 \text { children's } \\
\text { meals }\end{array}$ & $\begin{array}{l}\text { Australian } \\
\text { QSR and } \\
\text { FCR chains }\end{array}$ & $\begin{array}{l}\text { Fast-food } \\
\text { websites, } \\
\text { email and } \\
\text { telephone } \\
\text { requests, } \\
\quad \text { and } \\
\text { personnel } \\
\text { visits }\end{array}$ & $\begin{array}{l}\text { Children's meals per } \\
\text { restaurant chain }\end{array}$ & $\begin{array}{c}\text { Calories, saturated fat, } \\
\text { sodium and sugar. } \\
\text { Minimal changes } \\
\text { were found. Meals } \\
\text { from Chicken Treat } \\
\text { reduced mean energy } \\
\text { (-600 kJ/serving), } \\
\text { saturated fat } \\
(-9 \cdot 4 \mathrm{~g} / \mathrm{serving}) \text { and } \\
\mathrm{Na}(-121 \mathrm{mg} / \mathrm{serving}) \text {, } \\
\text { and from Red Rooster } \\
\text { (-410 kJ/serving) and } \\
\text { sugars } \\
(-11.8 \mathrm{~g} / \mathrm{serving}), \\
\mathrm{KFC} \text { reduced } \\
\text { saturated fat } \\
(-10 \cdot 5 \mathrm{~g} / \mathrm{serving}) \text {. } \\
\text { However, meals from } \\
\text { Hungry Jack's } \\
\text { increased in energy } \\
(345 \mathrm{~kJ} / \mathrm{serving}), \\
\text { sugars }(8 \cdot 6 \mathrm{~g} / \mathrm{serving}), \\
\text { and Na } \\
(187 \mathrm{mg} / \mathrm{serving})\end{array}$ & - & Mixed \\
\hline
\end{tabular}


Table 4. Cont.

\begin{tabular}{|c|c|c|c|c|c|c|c|c|c|c|}
\hline Author Year & Country & Study Design & Purpose & Sample & Setting & $\begin{array}{l}\text { Data } \\
\text { Sources }\end{array}$ & Menu Items & $\begin{array}{c}\text { Nutrition } \\
\text { Composition }\end{array}$ & $\begin{array}{l}\text { New vs. Common } \\
\text { Menu Items }\end{array}$ & Effect * \\
\hline $\begin{array}{l}\text { Wu et al. } \\
2014 \text { [56] }\end{array}$ & USA & $\begin{array}{l}\text { Observational, } \\
\text { longitudinal }\end{array}$ & $\begin{array}{l}\text { Track changes in the } \\
\text { energy and sodium } \\
\text { content of US chain } \\
\text { restaurant main } \\
\text { entrées between } \\
\text { spring } 2010 \text { (when the } \\
\text { Affordable Care Act } \\
\text { was passed) and } \\
\text { spring } 2011\end{array}$ & $\begin{array}{c}25,256 \text { regular } \\
\text { menu entrées } \\
\text { from } 213 \\
\text { restaurant brands }\end{array}$ & $\begin{array}{l}\text { Top US } \\
\text { chain } \\
\text { restaurants } \\
\text { based on } \\
2008 \text { sales }\end{array}$ & $\begin{array}{l}\text { Restaurant } \\
\text { websites, } \\
\text { and email } \\
\text { request }\end{array}$ & $\begin{array}{l}\text { Regular menu entrées } \\
\text { and children's menu } \\
\text { entrées }\end{array}$ & $\begin{array}{l}\text { Calories and sodium. } \\
26 \text { restaurants } \\
\text { reduced sodium in } \\
\text { newly added items by } \\
707 \text { mg on average. } \\
\text { Significant decrease in } \\
\text { mean energy } \\
(-40 \text { kcal. Two } \\
\text { upscale restaurants } \\
\text { with children's menu } \\
\text { entrées had a } \\
\text { significant increase in } \\
\text { mean energy ( } 46 \text { kcal). } \\
\text { Items removed from } \\
\text { children's menus } \\
\text { were } 36 \text { kcal lower }\end{array}$ & $\begin{array}{l}\text { Higher-sodium items } \\
\text { decreased by } 70 \mathrm{mg} \\
(p=0.027) \text { in added } \\
\text { vs. removed items on } \\
\text { regular menus. } \\
\text { Calories decreased by } \\
57 \mathrm{kcal}(p=0.047) \text { for } \\
\text { added vs. removed } \\
\text { children's entrées }\end{array}$ & Mixed \\
\hline
\end{tabular}

* Effect: positive (if results showed a statistically significant $p$-value), no effect (if results showed no statistically significant $p$-value or negative effects), and mixed-effects (if results showed

both) on menu labeling. QSR: quick-service restaurants; FCR: fast-casual restaurants; FSR: full-service restaurant. kJ: kilojoules. 


\subsubsection{Changes in the Nutritional Composition by Nutrients of Concern}

The effects of menu labeling were measured by changes in the nutrition composition of menu items for four nutrients of concern, including calories $(n=14)$, sodium $(n=5)$, saturated fat $(n=3)$, and sugar $(n=3)$. A single US study from Washington state did not use these nutrients; rather the authors classified healthy versus unhealthy items based on 10 items examined by the Nutrition Environment Measures Surveys-Restaurant version (NEMSR) [54]. Two studies from the US and one from Canada assessed serving size reductions of menu items $[16,47,54]$.

Positive effects: Bleich et al. (2020) reported the results of a longitudinal study (2012-2018) that examined nutrient trends for 28,238 food and beverage menu items from 28,238 US chain restaurants. The results found less calories in food items, and less calories and saturated fat in beverages, with results attributed to the US national menu labeling law [51]. Similar results were noted for six US studies that documented a significant decline in calories of certain items [19,48-50,53,55]. Besides energy, positive changes were reported for reducing the saturated fat and sodium content of menu items after the menu labeling implementation period in King County, Washington, that had more stringent menu labeling requirements before the national menu labeling law was passed in 2010 [16].

No effects: Two studies in Canada and Australia did not show significant results $[47,58]$. Saelens et al. (2012) reported that the availability of reduced portions actually decreased in King County, Washington, where menu labeling was implemented [54].

Mixed effects: Wu and Sturm (2014) assessed the energy and sodium changes from items offered by US chain restaurants after the national menu labeling law was passed in 2010 and in 2011. Results showed that QSR chains reduced the mean energy content of children's menu entrees by 40 calories; however, upscale restaurants had increased the mean energy content of children's menu entrees by 46 calories [56]. Similarly, Namba et al. (2013) examined the nutrient content of menu items after the national menu labeling law was passed in 2010 and in 2011, and found that the proportion of healthier menu items was higher in locations implementing restaurant labeling despite the mean calories of items that did not change [52]. Wellard-Cole et al. (2019) conducted a study in New South Wales, Australia, and found minimal decreases in energy, saturated fat, and sodium by specific QSR chains but and an increase in energy, sugars, and sodium from the QSR franchise called Hungry Jack's (Burger King) [59].

\subsubsection{Newly Introduced Menu Items Versus Common or Regular Menu Items}

Seven studies conducted in the US and Canada $[47-49,51,52,55,56]$ compared the differences between newly introduced menu items after the baseline year of the implementation of a menu labeling policy in 2018 with those that were dropped and/or stayed the same over the years. Five studies found positive effects [48,49,51,55,56], one study mixed effects [47], and one study found no effects [52].

Positive effects: Five US studies found significant changes made for newly introduced menu items that had fewer calories (from $-57 \mathrm{kcal}$ to $-285 \mathrm{kcal}$ ) relative to popular menu items that were offered regularly and consistently at the chain restaurants $[48,49,51,55,56]$.

No effects: Scourbutakos et al. (2019) investigated the early impact of the mandatory menu labeling law in the province of Ontario, Canada, that documented opposite results from the US studies that measured similar outcomes. The study found that newly introduced food items in 2017 contained more energy per serving compared with the newly introduced food items in 2016. The newly introduced menu items in 2017 also had significantly higher serving sizes compared with the newly introduced items from 2013 and 2016 [47].

Mixed effects: Namba et al. (2013) reported the results of a case-control study that examined five QSR chains that had voluntarily implemented menu labeling before the US national menu labeling law was passed in 2010. Three of the chains had improved the nutritional quality of items with healthier profiles of side dishes and children's meals. However, two chains showed no reduction in calories of any menu items [52]. 


\section{Discussion}

This is the first comprehensive review published to document the number of countries that have enacted menu labeling policies, to compare the features of these policies, and to examine evaluations about the effect of menu labeling policies on the business practices of transnational restaurant chains globally. Step 1 of the scoping review identified 11 menu labeling policies or laws enacted by national, state or provincial, and/or municipal authorities in upper-middle and high-income countries between 2010 and 2020. The governments in eight countries had enacted mandatory policies (i.e., Australia, Canada, Ireland, Saudi Arabia, South Korea, Taiwan, United Arab Emirates, and the US). The governments in three countries had enacted voluntary policies (i.e., Bahrain, Malaysia, and the UK). Step 2 of the scoping review summarizes the results and evidence gaps from 15 published studies (2012 to 2020) on existing menu labeling policies across four countries (i.e., Australia, Canada, the UK, and the US). Overall, the studies found mixed results, and only the US studies showed positive effects of restaurant menu labeling policies to reformulate items or introduce new healthier items ranging from 57calories to 285 fewer calories/item. Studies conducted in Australia, Canada, and the UK found either no effect or mixed effects of menu labeling policies on businesses to reformulate or introduce new menu offerings.

Step 2 of the scoping review revealed a major lack of published evidence for the effects of menu labeling on restaurant business for other regions of the world that have policies in place identified in step 1 (Table 2). No studies were found on the effects of menu labeling policies on restaurant food reformulation and serving sizes in the Asian region (i.e., Malaysia, South Korea, and Taiwan); Middle East region (i.e., Bahrain, Dubai, Saudi Arabia, and the United Arab Emirates); and European region (i.e., Ireland). This may have been due to no evaluations conducted, evaluations that were not available in the public domain, or published in languages other than English or Spanish.

The mandatory restaurant menu labeling policy compliance rate for disclosing energy (calories or kilojoules) was high in the US (94\% after May 2018) [75] and in New South Wales, Australia (95\%) [76]. However, subsequent evaluations in New South Wales showed that this compliance had not translated into restaurants making significant reductions in energy for menu items by 2016 [59]. A 2018 evaluation of restaurant menu labeling compliance across four Australian states (including New South Wales) and one territory showed high menu labeling compliance reported by 11 chain restaurants [77]. However, independent evaluations are needed to verify industry-reported results.

The menu labeling policies reviewed were found across upper-middle and high-income countries. However, the existing evidence highlights that eating away from home is increasing among populations creating room for menu labeling policies. The 2015 Nielsen Global Out-of-Home Dining Survey conducted among more than 30,000 adults in 61 countries found that about half of respondents (48\%) reported eating out one or more times weekly (REF). Consumers (22\%-26\%) in the Asia-Pacific region (i.e., Hong Kong, Taiwan, Malaysia and Thailand) reported eating out daily, and other countries with menu labeling legislation (i.e., Saudi Arabia and the US) reported rates of eating away from home daily $(12 \%-15 \%)$ that exceeded the global average of 9 percent [10]. The survey found that three out of the top five countries with the highest percentage of respondents that eat lunch away from home are in Latin America: Chile, Brazil, and Colombia [10]. Popkin and Reardon (2018) confirmed that since 1995, people are increasingly spending more of their income on eating out of home, with higher significant increases in Brazil, Chile, and Colombia [78]. A Nielsen Global Survey of food labeling trends among 25,000 consumers in 56 countries found that 80 percent of respondents expressed that fast-food restaurants should include calorie labeling and other nutrition information either sometimes or always, and, support was strongest in Latin America, North America and Europe [79]. Given these trends, there is a need to evaluate menu labeling policies of countries in these regions.

The small number of studies that assessed other nutrients of concern (i.e., saturated fats, trans fats, sodium, and added sugars) $[16,51,56,57,59]$ rather than just energy might be the consequence of policies limiting the regulation to reporting the energy content. All 11 countries that have implemented restaurant menu labeling policies require the disclosure of energy (i.e., calories or kilojoules). Only 
three countries (i.e., Australia, United Arab Emirates, and the US) require contextual information to display the daily energy intake recommended for the average adult (i.e., 2000 calories/day or 8700 kilojoules/day). Of these three countries, no evaluation was available for Dubai, and only two published evaluations were available for New South Wales, Australia, that found no significant effects. Results showed that two voluntary policies (Malaysia and Bahrain) and one mandatory policy (South Korea) included disclosure of fat, protein, sodium, and sugar besides calories. However, no evaluations were available to assess industry changes to reduce the availability of nutrients of concern (i.e., sodium, saturated fat, trans fat, and added sugar) linked to obesity, and diet-related NCDs have not been assessed yet.

It is important to note that the US studies showed a positive effect of menu labeling on restaurants to reduce calories for newly introduced items, especially appetizers and side dishes, may have been related to a longer time frame between the legislation enactment in 2010 and the published studies with positive effects (2015-2020) [16,19,48-51,53,55]. It is possible that the US restaurant sector had a longer period of time to implement changes that complied with the national law. Two US studies showed mixed results where the time factor could have influenced. Namba et al. (2013) evaluated the effect of menu labeling on QSR chain menus from 2005 through 2011, and most of the assessed years were before the national menu labeling law was passed [52]. In contrast, the menu labeling legislation passed in 2015 in Ontario, Canada, was implemented in January 2017. The Canadian study showed baseline data (2010-2016) no effects of menu labeling on the chain restaurants reformulating to offer healthier items [47]. Australia initiated mandatory menu labeling legislation in New South Wales in 2011, which was expanded to the Australian Canberra Territory and three states, including Victoria, which enacted mandatory menu labeling in 2018. The studies conducted in Australia showed both mixed [59] and no effect [58] of food reformulation or serving size reductions.

The type of policy might have influenced the study outcomes besides the time factor. The UK implemented a voluntary menu labeling policy that could have played a role in the mixed-effects found by Theis and Adams 2019 [57]. Several challenges are associated with mandatory policies enacted at the state or territorial levels (Australia) or the provincial level (Canada) that may lead to inconsistencies in legislation between jurisdictions and across the outlet threshold (chain versus non-chain), variations in the provision of voluntary, readable and standardized nutritional information to customers, and inability to customize menu ordering [77].

The study design may also explain the results from this review since the studies showing positive effects in the US were observational and longitudinal. The availability of longitudinal data from the MenuStat database could justify why the US studies showed positive effects for national menu labeling over eight years (2010-2018) compared to other countries that had a shorter time frame from the enactment of legislation. Experimental, quasi-experimental, and observational, case-control studies that compared non-regulated periods or jurisdiction versus regulated ones found no or mixed effects, respectively. This may indicate that industry changes may have happened for other reasons and/or policies independently from the menu labeling policy. In addition, studies that found positive effects have analyzed changes among items, and those that assessed effects among menus instead, have found no or mixed effects. These findings suggest that industry may have introduced positive changes to some items but kept the overall nutritional quality of the menu as a whole unchanged. The majority of study designs from the reviewed articles were observational, which cannot determine causation, and reverse causality needs to be explored. Restaurants could have changed their products before implementing menu labeling, or food businesses and non-restaurant businesses could have adopted pledges and commitments on items that are often offered in restaurants. Some recent US voluntary initiatives to improve the nutritional content of food and beverage products are the Healthy Weight Commitment [80] and the Children's Food and Beverage Advertising Initiative [81] in the US.

A robust body of evidence has shown that food reformulation may reduce or eliminate sodium and trans fats, both of which are identified by the WHO as a cost-effective strategy used across different countries to improve diet quality and reduce obesity and diet-related NCD risks [82-90]. Food and 
beverage product reformulation may have a greater impact on the entire population than strategies that encourage healthy choices that may or may not influence consumer behavior change because the decline in energy (calories or kilojoules) is distributed across populations that frequently consume the modified products $[88,91,92]$.

Our scoping review results identified several challenges. First, evaluations were published for only four of 11 countries that had passed legislation between 2010 and 2020. This suggests that policymakers are not investing adequate resources to monitor and evaluate the effects of menu labeling policies. Second, only the US studies that evaluated the effects of a mandatory national policy showed that restaurants had reduced calories for some newly introduced menu item categories, but did not reduce calories or the serving sizes of popular items frequently consumed. This is a challenge because expert bodies have recommended nutrient targets for menu item categories that are not being used as reference points to evaluate industry progress [21]. Third, while the WHO has recommended nutrition labeling and reducing portion sizes as strategies to reduce energy intake, our study found no evidence to support menu labeling legislation as a cost-effectiveness "best buy" strategy to reduce NCD-related disability and mortality in low- and middle-income countries [14].

\subsection{Implications for Policy, Practice, and Research}

Our results suggest that menu labeling legislation in the absence of other supportive strategies is unlikely to produce a meaningful change among restaurant practices to expand healthy menu items for all customers. Menu labeling is one of eight marketing-mix and choice architecture strategies that restaurant businesses can use to nudge customers toward healthy food environments $20[93,94]$. A compelling business case must be made to persuade chain restaurants to adopt these strategies to improve their corporate image and attract new customers who want healthy meals [95].

Table 5 suggests several actions for stakeholders, including governments, the WHO, restaurant businesses, private foundations, researchers, and civil society organizations to develop, implement, and evaluate comprehensive restaurant menu labeling policies.

Table 5. Recommended actions for stakeholders to develop, implement, and evaluate comprehensive restaurant menu labeling policies.

\begin{tabular}{cc}
\hline Food System Actors & Recommended Actions \\
\hline Governments & $\begin{array}{c}\text { Provide enough support for food service restaurant businesses to facilitate a } \\
\text { low-cost, sustainable, and accountable policy. Policies could be improved to } \\
\text { incentivize more holistic menu changes by requiring the display of energy and } \\
\text { other nutrients of concern, including fats, sodium, and added sugars for each } \\
\text { item offered by restaurants. }\end{array}$ \\
\hline World Health Organization & $\begin{array}{c}\text { Issue recommendations for governments and transnational restaurants and their } \\
\text { franchise businesses, and food service providers to harmonize, standardize, and } \\
\text { apply a universal set of healthy dietary standards across countries and regions. }\end{array}$ \\
\hline Restaurant businesses & $\begin{array}{c}\text { Make commitments and increase transparency to meet product profile targets } \\
\text { based on WHO- or expert-recommended guidelines }\end{array}$ \\
\hline Private foundations & $\begin{array}{c}\text { Provide technical assistance and incentivize transnational restaurant chains to } \\
\text { implement, monitor, and evaluate menu labeling policies across countries } \\
\text { and regions. }\end{array}$ \\
\hline Researchers & $\begin{array}{c}\text { Expand external monitoring and evaluation efforts of transnational restaurant } \\
\text { chains to assess their compliance with WHO- or expert-recommended guidelines } \\
\text { across countries and regions. Examine how digital technology could be used to } \\
\text { leverage the effects of restaurant menu labeling policies. }\end{array}$ \\
\hline Civil society organizations & $\begin{array}{c}\text { Use social media advocacy, public awareness campaigns, and shareholder } \\
\text { resolutions to encourage governments to implement comprehensive restaurant } \\
\text { menu labeling policies for healthy product reformulation and portion size } \\
\text { reduction for products sold to customers across countries and regions. }\end{array}$
\end{tabular}


Government action is needed to implement national comprehensive menu labeling policies to have a significant effect on food reformulation and serving size reduction. Evidence still needs to be stronger to confirm these positive effects, and it is clear that voluntary efforts by industry are not enough. Only one study [57], based on the UK voluntary policy, discussed that food business initiatives and goodwill are insufficient for restaurant menu labeling to become a cost-effective strategy to address obesity and diet-related NCDs. Littlewood et al. (2016) have suggested that restaurants are more likely to improve their performance to offer healthier options with mandatory government requirements [25].

Digital technologies (i.e., online ordering through apps and digital menu boards) are being used more frequently to reach more customers that may either support or undermine the positive effect of menu labeling. The coronavirus or COVID-19 pandemic has created a new trend where restaurant businesses have moved to digital online and delivery, in response to the economic crisis that the pandemic has caused worldwide. Future policies and research should examine how restaurants change menu items based on customers' online ordering experience, use of onsite digital technology computerized touch screens and smartphones, use of algorithmic nudging to influence customers' choices, and how customers use digital technologies available through third-party delivery apps and businesses such as UberEats and DoorDash. Research could also examine how to leverage digital technology to encourage menu item reformulation and serving size reductions while encouraging customers to purchase the healthiest menu items [96].

Effective policy actions require regulatory oversight to ensure accountability [97]. The engagement of diverse sectors will help to strengthen the accountability process. Civil society organizations should mobilize efforts to support restaurant menu labeling initiatives and can perform independent evaluations that are shared with industry actors and government regulatory bodies. It is common for the industry sector to oppose these initiatives based on evidence from Ireland [67] and in the UK [69], where national menu labeling has been under consideration by Congress since 2015 .

This research adds to the literature by identifying the knowledge gaps about the effects of restaurant and fast-food chain menu labeling on food reformulation and serving size reductions. Further research is needed to assess ongoing restaurant menu labeling policies from the Americas region (especially Latin and Central American countries), European, Eastern Mediterranean, African and Western Pacific regions for the short-term, mid-term, and long-term effects. More research is needed to explore whether restaurant menu labeling can reduce serving sizes of menu items in middle-and low-income countries. Experimental studies are needed to explore reverse causation and whether restaurant menu labeling policies will be effective in different countries by context. Finally, the WHO has clearly stated that obesity and NCDs are risk factors for COVID-19 [98]. Governments are implementing "new guidelines" for re-opening business and reset the economy and should prioritize in their political agenda policies that encourage healthier food environments to ensure that nutritious food is available for all populations as an integral strategy.

\subsection{Study Strengths and Limitations}

This scoping review has several limitations common to the nature of the study (i.e., map, describe, and provide an overview of the published literature to identify relevant data to inform policymaking and research). The exploratory scope of this review does not enable conclusions about the topic. However, these results may provide valuable insights for research and policy actions, especially regarding the monitoring and evaluation of implemented policies within and across countries to rigorously understand whether and under what conditions menu labeling could have an effect on restaurant businesses. It is possible that the use of additional literature databases would have yielded further articles. Given the involvement of an expert librarian, it was anticipated that the selected databases were appropriate to capture the breadth of research on this topic. In addition, this review also assessed the quality of the selected studies. We limited the search date to 2000. No studies that met the inclusion criteria were found between 2000 and 2011; therefore, we believe that our search captured the majority of relevant articles for the topic. Literature in other languages than English and 
Spanish were excluded, so research for countries that had legislation and evaluations published in other languages may have been missed. Lastly, all the selected studies were conducted in high-income countries; therefore, these results cannot be generalized to middle- or low-income country settings.

\section{Conclusions}

The trend of increased eating away from home across countries is a call for mandatory menu labeling policies to improve healthy offerings to support a healthy diet worldwide. The overall evidence from this review is mixed on the effect of menu labeling policies for transnational restaurants and fast-food chains on food reformulation. The positive effects were from observational and longitudinal studies conducted within the period the legislation was enacted in the US and mainly for food reformulation of the energy content of menu items, and the introduction of new healthier menu items, not for overall changes among the menus. Case-control and quasi-experimental studies found no or mixed effects. Considerable gaps in the evidence remain, particularly regarding the effects of the implemented policies across regions at mid- and long-term, research in middle- and low-income countries, and reverse causation of restaurant menu labeling policies. Moreover, while all the enacted policies across countries request to display energy content, additional nutrients of concern could be included to have a greater impact. These results may inform governments, civil society, academics, and the restaurant industry to develop comprehensive and robust restaurant menu labeling policies that promote healthy dietary choices to reduce obesity and NCD risks worldwide.

Supplementary Materials: The following are available online at http:/www.mdpi.com/2072-6643/12/6/1544/s1. Table S1: MeSH terms definitions. Table S2: Search details on each database. Table S3: Quality assessment results based on the Johanna Briggs Institute critical appraisal checklist.

Author Contributions: S.R.-G.P. led the study conception, methodology, data collection, formal analysis, and original draft manuscripts. The co-authors contributed as follows: Conceptualization, V.I.K., V.H., and E.S.; methodology, M.Z.; validation, M.Z. and V.I.K.; writing-review and editing, M.Z., V.H., E.S., R.L., F.D.S.G., and V.I.K. F.D.S.G. is a staff member of the Pan American Health Organization. The authors alone are responsible for the views expressed in this publication, and they do not necessarily represent the decisions or policies of the Pan American Health Organization. All authors have read and agreed to the published version of the manuscript.

Funding: We are grateful for the financial support provided by Virginia Tech Library's Open Access Subvention Fund to cover the publication and open access costs for this manuscript. In any use of this publication, there should be no suggestion that PAHO endorses specific organizations, products, or services.

Acknowledgments: The authors greatly appreciate Erin Smith for her guidance and input on developing the research question, finding the appropriate $\mathrm{MeSH}$ terms for the scoping review, and selecting the appropriate databases. We thank Sara Hendery and Jessica Agnew for their help in proofreading the manuscript.

Conflicts of Interest: The authors declare no conflict of interest.

\section{References}

1. Popkin, B.M. Relationship between shifts in food system dynamics and acceleration of the global nutrition transition. Nutr. Rev. 2017, 75, 73-82. [CrossRef] [PubMed]

2. Smith, L.P.; Ng, S.W.; Popkin, B.M. Resistant to the recession: Low-income adults' maintenance of cooking and away-from-home eating behaviors during times of economic turbulence. Am. J. Public Health 2014, 104, 840-846. [CrossRef] [PubMed]

3. Vandevijvere, S.; Jaacks, L.M.; Monteiro, C.A.; Moubarac, J.C.; Girling-Butcher, M.; Lee, A.C.; Pan, A.; Bentham, J.; Swinburn, B. Global trends in ultraprocessed food and drink product sales and their association with adult body mass index trajectories. Obes. Rev. 2019, 20 (Suppl. 2), 10-19. [CrossRef] [PubMed]

4. Kant, A.K.; Graubard, B.I. A prospective study of frequency of eating restaurant prepared meals and subsequent 9-year risk of all-cause and cardiometabolic mortality in US adults. PLoS ONE 2018, 13, e0191584. [CrossRef] [PubMed]

5. Seguin, R.A.; Aggarwal, A.; Vermeylen, F.; Drewnowski, A. Consumption Frequency of Foods Away from Home Linked with Higher Body Mass Index and Lower Fruit and Vegetable Intake among Adults: A Cross-Sectional Study. J. Environ. Public Health 2016, 2016, 3074241. [CrossRef] 
6. Alturki, H.A.; Brookes, D.S.; Davies, P.S. Comparative evidence of the consumption from fast-food restaurants between normal-weight and obese Saudi schoolchildren. Public Health Nutr. 2018, 21, 2280-2290. [CrossRef]

7. Tambalis, K.D.; Panagiotakos, D.B.; Psarra, G.; Sidossis, L.S. Association between fast-food consumption and lifestyle characteristics in Greek children and adolescents; results from the EYZHN (National Action for Children's Health) programme. Public Health Nutr. 2018, 21, 3386-3394. [CrossRef] [PubMed]

8. Llanaj, E.; Ádány, R.; Lachat, C.; D'Haese, M. Examining food intake and eating out of home patterns among university students. PLoS ONE 2018, 13, e0197874. [CrossRef]

9. Goffe, L.; Rushton, S.; White, M.; Adamson, A.; Adams, J. Relationship between mean daily energy intake and frequency of consumption of out-of-home meals in the UK National Diet and Nutrition Survey. Int. J. Behav. Nutr. Phys. Act. 2017, 14, 131. [CrossRef]

10. Nielsen. Nielsen Global Out-of-Home Dining Survey; The Nielsen Company: New York, NY, USA, 2015.

11. Kuo, T.; Jarosz, C.J.; Simon, P.; Fielding, J.E. Menu labeling as a potential strategy for combating the obesity epidemic: A health impact assessment. Am. J. Public Health 2009, 99, 1680-1686. [CrossRef]

12. Cawley, J.; Wen, K. Policies to Prevent Obesity and Promote Healthier Diets: A Critical Selective Review. Clin. Chem. 2018, 64, 163-172. [CrossRef] [PubMed]

13. World health Organization. Follow-up to the Political Declaration of the High-Level Meeting of the General Assembly WHA66.10. Annex: Global Action Plan for Prevention and Control of Non-Communicable Diseases 2013-2020; World Health Organization: Geneva, Switzerland, 2013.

14. World Health Organization. Tackling NCDs: 'Best Buys' and other Recommended Interventions for the Prevention and Control of Noncommunicable Diseases; World Health Organization: Geneva, Switzerland, 2017.

15. Bleich, S.N.; Economos, C.D.; Spiker, M.L.; Vercammen, K.A.; VanEpps, E.M.; Block, J.P.; Elbel, B.; Story, M.; Roberto, C.A. A Systematic Review of Calorie Labeling and Modified Calorie Labeling Interventions: Impact on Consumer and Restaurant Behavior. Obesity 2017, 25, 2018-2044. [CrossRef] [PubMed]

16. Bruemmer, B.; Krieger, J.; Saelens, B.E.; Chan, N. Energy, saturated fat, and sodium were lower in entrees at chain restaurants at 18 months compared with 6 months following the implementation of mandatory menu labeling regulation in King County, Washington. J. Acad. Nutr. Diet. 2012, 112, 1169-1176. [CrossRef] [PubMed]

17. Muth, M.K.; Karns, S.A.; Mancino, L.; Todd, J.E. How Much Can Product Reformulation Improve Diet Quality in Households with Children and Adolescents? Nutrients 2019, 11, 618. [CrossRef]

18. Federici, C.; Detzel, P.; Petracca, F.; Dainelli, L.; Fattore, G. The impact of food reformulation on nutrient intakes and health, a systematic review of modelling studies. BMC Nutr. 2019, 5, 2. [CrossRef]

19. Bleich, S.N.; Moran, A.J.; Jarlenski, M.P.; Wolfson, J.A. Higher-Calorie Menu Items Eliminated in Large Chain Restaurants. Am. J. Prev. Med. 2018, 54, 214-220. [CrossRef]

20. Kraak, V.; Englund, T.; Misyak, S.; Serrano, E. Progress Evaluation for the Restaurant Industry Assessed by a Voluntary Marketing-Mix and Choice-Architecture Framework that Offers Strategies to Nudge American Customers toward Healthy Food Environments, 2006-2017. Int. J. Environ. Res. Public Health 2017, 760. [CrossRef]

21. Kraak, V.; Rincon-Gallardo Patino, S.; Renukuntla, D.; Kim, E. Progress Evaluation for Transnational Restaurant Chains to Reformulate Products and Standardize Portions to Meet Healthy Dietary Guidelines and Reduce Obesity and Non-Communicable Disease Risks, 2000-2018: A Scoping and Systematic Review to Inform Policy. Int. J. Environ. Res. Public Health 2019, 2732. [CrossRef]

22. Fernandes, A.C.; Oliveira, R.C.; Proenca, R.P.; Curioni, C.C.; Rodrigues, V.M.; Fiates, G.M. Influence of menu labeling on food choices in real-life settings: A systematic review. Nutr. Rev. 2016, 74, 534-548. [CrossRef]

23. Harnack, L.J.; French, S.A. Effect of point-of-purchase calorie labeling on restaurant and cafeteria food choices: A review of the literature. Int. J. Behav. Nutr. Phys. Act. 2008, 5, 51. [CrossRef]

24. Kiszko, K.M.; Martinez, O.D.; Abrams, C.; Elbel, B. The influence of calorie labeling on food orders and consumption: A review of the literature. J. Community Health 2014, 39, 1248-1269. [CrossRef] [PubMed]

25. Littlewood, J.A.; Lourenco, S.; Iversen, C.L.; Hansen, G.L. Menu labelling is effective in reducing energy ordered and consumed: A systematic review and meta-analysis of recent studies. Public Health Nutr. 2016, 19, 2106-2121. [CrossRef] [PubMed]

26. Long, M.W.; Tobias, D.K.; Cradock, A.L.; Batchelder, H.; Gortmaker, S.L. Systematic review and meta-analysis of the impact of restaurant menu calorie labeling. Am. J. Public Health 2015, 105, e11-e24. [CrossRef] [PubMed] 
27. Sinclair, S.E.; Cooper, M.; Mansfield, E.D. The influence of menu labeling on calories selected or consumed: A systematic review and meta-analysis. J. Acad. Nutr. Diet. 2014, 114, 1375-1388.e15. [CrossRef] [PubMed]

28. Swartz, J.J.; Braxton, D.; Viera, A.J. Calorie menu labeling on quick-service restaurant menus: An updated systematic review of the literature. Int. J. Behav. Nutr. Phys. Act. 2011, 8, 135. [CrossRef] [PubMed]

29. VanEpps, E.M.; Roberto, C.A.; Park, S.; Economos, C.D.; Bleich, S.N. Restaurant Menu Labeling Policy: Review of Evidence and Controversies. Curr. Obes. Rep. 2016, 5, 72-80. [CrossRef]

30. Sarink, D.; Peeters, A.; Freak-Poli, R.; Beauchamp, A.; Woods, J.; Ball, K.; Backholer, K. The impact of menu energy labelling across socioeconomic groups: A systematic review. Appetite 2016, 99, 59-75. [CrossRef] [PubMed]

31. Cantu-Jungles, T.M.; McCormack, L.A.; Slaven, J.E.; Slebodnik, M.; Eicher-Miller, H.A. A Meta-Analysis to Determine the Impact of Restaurant Menu Labeling on Calories and Nutrients (Ordered or Consumed) in U.S. Adults. Nutrients 2017, 1088. [CrossRef]

32. Crockett, R.A.; King, S.E.; Marteau, T.M.; Prevost, A.T.; Bignardi, G.; Roberts, N.W.; Stubbs, B.; Hollands, G.J.; Jebb, S.A. Nutritional labelling for healthier food or non-alcoholic drink purchasing and consumption. Cochrane Database Syst. Rev. 2018. [CrossRef]

33. Sucharew, H.; Macaluso, M. Progress Notes: Methods for Research Evidence Synthesis: The Scoping Review Approach. J. Hosp. Med. 2019, 14, 416-418. [CrossRef]

34. World Health Organization. Global Database on the Implementation of Nutrition Action (GINA); World Health Organization: Geneva, Switzerland, 2012.

35. Hawkes, C.; Jewell, J.; Allen, K. A food policy package for healthy diets and the prevention of obesity and diet-related non-communicable diseases: The NOURISHING framework. Obes. Rev. 2013, 14, 159-168. [CrossRef] [PubMed]

36. World Cancer Research Fund International. NOURISHING Framework; World Cancer Research Fund International: London, UK, 2017.

37. Arksey, H.; O'Malley, L. Scoping studies: Towards a methodological framework. Int. J. Soc. Res. Methodol. 2005, 8, 19-32. [CrossRef]

38. Daudt, H.M.L.; van Mossel, C.; Scott, S.J. Enhancing the scoping study methodology: A large, inter-professional team's experience with Arksey and O'Malley's framework. BMC Med Res. Methodol. 2013, 13, 48. [CrossRef] [PubMed]

39. Doody, O.; Bailey, M.E. Setting a research question, aim and objective. Nurse Res. 2016, 23, 19-23. [CrossRef] [PubMed]

40. Moola, S.; Munn, Z.; Sears, K.; Sfetcu, R.; Currie, M.; Lisy, K.; Tufanaru, C.; Qureshi, R.; Mattis, P.; Mu, P. Conducting systematic reviews of association (etiology): The Joanna Briggs Institute's approach. Int. J. Evid. -Based Healthc. 2015, 13, 163-169. [CrossRef]

41. Richardson, W.S.; Wilson, M.C.; Nishikawa, J.; Hayward, R.S. The well-built clinical question: A key to evidence-based decisions. ACP J. Club 1995, 123, A12-A13.

42. Veritas Health. Covidence Systematic Review Software; Melbourne, Australia. 2019. Available online: https://www.medianet.com.au/releases/162025 (accessed on 15 February 2020).

43. Tricco, A.C.; Lillie, E.; Zarin, W.; O’Brien, K.K.; Colquhoun, H.; Levac, D.; Moher, D.; Peters, M.D.J.; Horsley, T.; Weeks, L.; et al. PRISMA Extension for Scoping Reviews (PRISMA-ScR): Checklist and Explanation. Ann. Intern. Med. 2018, 169, 467-473. [CrossRef]

44. The Johana Briggs Institute. Checklist for Analytical Obesravtional Studies; The University of Adelaide: Adelaide, Australia, 2017.

45. Ryan, R. Cochrane Consumer and Communication Review Group: Data Synthesis and Analysis. 2013. Available online: https://cccrg.cochrane.org/sites/cccrg.cochrane.org/files/public/uploads/Analysis.pdf (accessed on 15 January 2020).

46. Castleberry, A.; Nolen, A. Thematic analysis of qualitative research data: Is it as easy as it sounds? Curr. Pharm. Teach. Learn. 2018, 10, 807-815. [CrossRef]

47. Scourboutakos, M.J.; Orr, S.; Hobin, E.; Murphy, S.A.; Manson, H.; L'Abbé, M.R. Assessing the Early Impact of Menu-Labeling on Calories in Chain Restaurants in Ontario, Canada. Am. J. Prev. Med. 2019, 56, e195-e203. [CrossRef] 
48. Bleich, S.N.; Wolfson, J.A.; Jarlenski, M.P.; Block, J.P. Restaurants With Calories Displayed On Menus Had Lower Calorie Counts Compared To Restaurants Without Such Labels. Health Aff. 2015, 34, 1877-1884. [CrossRef]

49. Bleich, S.N.; Wolfson, J.A.; Jarlenski, M.P. Calorie Changes in Large Chain Restaurants: Declines in New Menu Items but Room for Improvement. Am. J. Prev. Med. 2016, 50, e1-e8. [CrossRef] [PubMed]

50. Bleich, S.N.; Wolfson, J.A.; Jarlenski, M.P. Calorie changes in large chain restaurants from 2008 to 2015. Prev. Med. 2017, 100, 112-116. [CrossRef] [PubMed]

51. Bleich, S.N.; Soto, M.J.; Dunn, C.G.; Moran, A.J.; Block, J.P. Calorie and nutrient trends in large U.S. chain restaurants, 2012-2018. PLoS ONE 2020, 15, e0228891. [CrossRef] [PubMed]

52. Namba, A.; Auchincloss, A.; Leonberg, B.L.; Wootan, M.G. Exploratory analysis of fast-food chain restaurant menus before and after implementation of local calorie-labeling policies, 2005-2011. Prev. Chronic Dis. 2013, 10, E101. [CrossRef] [PubMed]

53. Petimar, J.; Zhang, F.; Cleveland, L.P.; Simon, D.; Gortmaker, S.L.; Polacsek, M.; Bleich, S.N.; Rimm, E.B.; Roberto, C.A.; Block, J.P. Estimating the effect of calorie menu labeling on calories purchased in a large restaurant franchise in the southern United States: Quasi-experimental study. BMJ 2019, 367, 15837. [CrossRef] [PubMed]

54. Saelens, B.E.; Chan, N.L.; Krieger, J.; Nelson, Y.; Boles, M.; Colburn, T.A.; Glanz, K.; Ta, M.L.; Bruemmer, B. Nutrition-labeling regulation impacts on restaurant environments. Am. J. Prev. Med. 2012, 43, 505-511. [CrossRef]

55. Tran, A.; Moran, A.; Bleich, S.N. Calorie changes among food items sold in U.S. convenience stores and pizza restaurant chains from 2013 to 2017. Prev. Med. Rep. 2019, 15, 100932. [CrossRef]

56. Wu, H.W.; Sturm, R. Changes in the energy and sodium content of main entrees in US chain restaurants from 2010 to 2011. J. Acad. Nutr. Diet. 2014, 114, 209-219. [CrossRef]

57. Theis, D.R.Z.; Adams, J. Differences in energy and nutritional content of menu items served by popular UK chain restaurants with versus without voluntary menu labelling: A cross-sectional study. PLoS ONE 2019, 14, e0222773. [CrossRef]

58. Wellard-Cole, L.; Goldsbury, D.; Havill, M.; Hughes, C.; Watson, W.L.; Dunford, E.K.; Chapman, K. Monitoring the changes to the nutrient composition of fast foods following the introduction of menu labelling in New South Wales, Australia: An observational study. Public Health Nutr. 2018, 21, 1194-1199. [CrossRef]

59. Wellard-Cole, L.; Hooper, A.; Watson, W.L.; Hughes, C. Nutrient composition of Australian fast-food and fast-casual children's meals available in 2016 and changes in fast-food meals between 2010 and 2016. Public Health Nutr. 2019, 22, 2981-2988. [CrossRef] [PubMed]

60. World Health Organization. Health Statistics and Information Systems. Definition of Regional Grouping; Global Health Estimates: Geneva, Switzerland, 2020.

61. Food and Drug Administration. Food Labeling: Revision of the Nutrition and Supplement Facts Labels. In Final Rule. Fed. Regist; 2016; 81, pp. 33741-33999. Available online: https://pubmed.ncbi.nlm.nih.gov/ 27236870/ (accessed on 15 January 2020).

62. Obesity Policy Coalition. Policy Brief: Menu Kilojoule Labelling in Chain Food Outlets in Australia; 2018. Available online: https://www.opc.org.au/downloads/policy-briefs/menu-kj-labelling-in-chain-food-outletsin-australia.pdf (accessed on 15 January 2020).

63. Legislative Assembly of the Province of Ontario, Canada. Healthy Menu Choices Act, 2015 (Bill 45, Making Healthier Choices Act) O.Reg.50/16; Canada, G.o., Ed.; Ontario, Canada. 2017. Available online: https: //labbelab.utoronto.ca/wp-content/uploads/2017/12/Evidence-Document-ON-reformat-Nov-8.pdf (accessed on 15 January 2020).

64. Food Safety Awareness and Applied Nutrition Unit; Department, F.S. Calorie Labeling in Food Service Establishments. In Requirements and Guidelines; Dubai Municipality: Dubai, United Arab Emirates, 2019. Available online: http://www.foodsafe.ae/pic/requirements/Calorie_Labeling_in_Food_Service_ Establishments_Requirements_and_Guidelines_1907.pdf (accessed on 15 January 2020).

65. Ministry of Health Malaysia. National Plan of Action for Nutrition of Malaysia (2016-2025); Nutrition Division, M.o.H.M., Ed.; Putrajaya, Malaysia. 2016. Available online: http://nutrition.moh.gov.my/wpcontent/uploads/2016/12/NPANM_III.pdf (accessed on 15 January 2020). 
66. A'Ali, M. Bahrain News: Proposal for Restaurants and Cafés to Display Calories in Meals. GDNonline, 22 September. 2018. Available online: http://www.gdnonline.com/Details/402212/Proposal-for-restaurants-andcaf\%E9s-to-display-calories-in-meals (accessed on 15 February 2020).

67. Department of Health. Consultation with Food Businesses on the Introduction of Mandatory Calorie Posting on Menus; Health, G.o.i.D.o., Ed.; 2020. Available online: https://www.gov.ie/en/consultation/d9bfccconsultation-with-food-businesses-on-the-introduction-of-mandatory-c/ (accessed on 15 January 2020).

68. British Nutrition Foundation. The Public Health Responsibility Deal; Scotland. 2018. Available online: https://www.nutrition.org.uk (accessed on 15 January 2020).

69. Department of health and Social Care. Mandating Energy Labelling of Food and Drink in Out-of-Home Settings; IA No:13009; Department of health and Social Care: UK. 2018. Available online: https://assets.publishing.service.gov.uk/government/uploads/system/uploads/attachment_data/file/751532/ impact-assessment-for-consultation-on-calorie-labelling-outside-of-the-home.pdf (accessed on 15 January 2020).

70. Secretary of State for Health and Social Care. Government Response to the House of Commons Health and Social Care Select Committee Report on Childhood Obesity: Time for Action, Eight Report of Session 2017-19; London, UK. 2019. Available online: https:/www.parliament.uk/documents/commons-committees/Health/ Correspondence/2017-19/Childhood-obesity-Government-Response-to-eighth-report-17-19.pdf (accessed on 15 January 2020).

71. Dame Sally Davies. Time to Solve Childhood Obesity. An Independent Report by the Chief Medical Officer. Annex A-Recommendations for Action. 2019. Available online: https://assets.publishing.service.gov.uk/government/uploads/system/uploads/attachment_data/file/ 837907/cmo-special-report-childhood-obesity-october-2019.pdf (accessed on 15 January 2020).

72. Center for Disease Control and Prevention. CDC Policy Process: Definition of Policy. In Office of the Associate Director for Policy; 2015. Available online: https://www.cdc.gov/policy/analysis/process/index.html (accessed on 15 January 2020).

73. Scourboutakos, M.J.; Semnani-Azad, Z.; L'Abbe, M.R. Added sugars in kids' meals from chain restaurants. Prev. Med. Rep. 2016, 3, 391-393. [CrossRef] [PubMed]

74. Scourboutakos, M.J.; L'Abbe, M.R. Restaurant menus: Calories, caloric density, and serving size. Am. J. Prev. Med. 2012, 43, 249-255. [CrossRef] [PubMed]

75. Cleveland, L.P.; Simon, D.; Block, J.P. Federal calorie labelling compliance at US chain restaurants. Obes. Sci. Pract. 2019. [CrossRef]

76. Wellard, L.; Havill, M.; Hughes, C.; Watson, W.L.; Chapman, K. The availability and accessibility of nutrition information in fast food outlets in five states post-menu labelling legislation in New South Wales. Aust. N. Z. J. Public Health 2015, 39, 546-549. [CrossRef]

77. Sacks, G.; Robinson, E. Inside Our Quick Service Restaurants: Assessment of Company Policies and Commitments Related to Obesity Prevention and Nutrition; Deakin University: Melbourne, Australia, 2018.

78. Popkin, B.; Reardon, T. Obesity and the food system transformation in Latin America. Obes. Rev. 2018, 19, 1028-1064. [CrossRef]

79. Nielsen. Battle of the Bulge \& Nutrition Labels. Healthy Eating Trends Around the World; The Nielsen Company: New York, NY, USA, 2012.

80. Healthy Weight Commitment Foundation. Food and Beverage Manufacterers Pledging to Reduce Annual Calories By 1.5 Trillion By 2015; CISION PR Newswire: London, UK, 2010.

81. Children's Food \& Beverage Advertising Initiative. Advertising Initiative Category-Specific Uniform Nutrition Criteria; Council of Better Business Bureaus, Inc.: Arlington, VA, USA, 2018.

82. Mantilla Herrera, A.M.; Crino, M.; Erskine, H.E.; Sacks, G.; Ananthapavan, J.; Mhurchu, C.N.; Lee, Y.Y. Cost-Effectiveness of Product Reformulation in Response to the Health Star Rating Food Labelling System in Australia. Nutrients 2018, 10, 614. [CrossRef]

83. Pearson-Stuttard, J.; Hooton, W.; Critchley, J.; Capewell, S.; Collins, M.; Mason, H.; Guzman-Castillo, M.; O'Flaherty, M. Cost-effectiveness analysis of eliminating industrial and all trans fats in England and Wales: Modelling study. J. Public Health 2017, 39, 574-582. [CrossRef]

84. Shangguan, S.; Afshin, A.; Shulkin, M.; Ma, W.; Marsden, D.; Smith, J.; Saheb-Kashaf, M.; Shi, P.; Micha, R.; Imamura, F.; et al. A Meta-Analysis of Food Labeling Effects on Consumer Diet Behaviors and Industry Practices. Am. J. Prev. Med. 2019, 56, 300-314. [CrossRef] 
85. Wilcox, M.L.; Mason, H.; Fouad, F.M.; Rastam, S.; al Ali, R.; Page, T.F.; Capewell, S.; O’Flaherty, M.; Maziak, W. Cost-effectiveness analysis of salt reduction policies to reduce coronary heart disease in Syria, 2010-2020. Int. J. Public Health 2015, 60 (Suppl. 1), S23-S30. [CrossRef]

86. Watkins, D.A.; Olson, Z.D.; Verguet, S.; Nugent, R.A.; Jamison, D.T. Cardiovascular disease and impoverishment averted due to a salt reduction policy in South Africa: An extended cost-effectiveness analysis. Health Policy Plan 2016, 31, 75-82. [CrossRef] [PubMed]

87. Mason, H.; Shoaibi, A.; Ghandour, R.; O’Flaherty, M.; Capewell, S.; Khatib, R.; Jabr, S.; Unal, B.; Sozmen, K.; Arfa, C.; et al. A cost effectiveness analysis of salt reduction policies to reduce coronary heart disease in four Eastern Mediterranean countries. PLoS ONE 2014, 9, e84445. [CrossRef] [PubMed]

88. Spiteri, M.; Soler, L.G. Food reformulation and nutritional quality of food consumption: An analysis based on households panel data in France. Eur. J. Clin. Nutr. 2018, 72, 228-235. [CrossRef] [PubMed]

89. Downs, S.M.; Bloem, M.Z.; Zheng, M.; Catterall, E.; Thomas, B.; Veerman, L.; Wu, J.H. The Impact of Policies to Reduce trans Fat Consumption: A Systematic Review of the Evidence. Curr. Dev. Nutr. 2017, 1. [CrossRef] [PubMed]

90. Hendry, V.L.; Almiron-Roig, E.; Monsivais, P.; Jebb, S.A.; Neelon, S.E.; Griffin, S.J.; Ogilvie, D.B. Impact of regulatory interventions to reduce intake of artificial trans-fatty acids: A systematic review. Am. J. Public Health 2015, 105, e32-e42. [CrossRef] [PubMed]

91. Griffith, R.; O'Connell, M.; Smith, K. The Importance of Product Reformulation Versus Consumer Choice in Improving Diet Quality. Economica 2017, 84, 34-53. [CrossRef]

92. Leroy, P.; Requillart, V.; Soler, L.G.; Enderli, G. An assessment of the potential health impacts of food reformulation. Eur. J. Clin. Nutr. 2016, 70, 694-699. [CrossRef]

93. Kraak, V.I.; Englund, T.; Misyak, S.; Serrano, E.L. A novel marketing mix and choice architecture framework to nudge restaurant customers toward healthy food environments to reduce obesity in the United States. Obes. Rev. 2017, 18, 852-868. [CrossRef]

94. Roberto, C.A.; Khandpur, N. Improving the design of nutrition labels to promote healthier food choices and reasonable portion sizes. Int. J. Obes. 2014, 38 (Suppl. 1), S25-S33. [CrossRef]

95. Kerins, C.; McHugh, S.; McSharry, J.; Reardon, C.M.; Hayes, C.; Perry, I.J.; Geaney, F.; Seery, S.; Kelly, C. Barriers and facilitators to implementation of menu labelling interventions from a food service industry perspective: A mixed methods systematic review. Int. J. Behav. Nutr. Phys. Act. 2020, 17, 48. [CrossRef]

96. Burke-Garcia, A.; Scally, G. Trending now: Future directions in digital media for the public health sector. J. Public Health 2014, 36, 527-534. [CrossRef] [PubMed]

97. World Health Organization. Health Laws and Universal Health Coverage; World Health Organization: Geneva, Switzerland, 2020.

98. World Health Organization. Information Note on COVID-19 and NCDs; World Health Organization: Geneva, Switzerland, 2020.

(C) 2020 by the authors. Licensee MDPI, Basel, Switzerland. This article is an open access article distributed under the terms and conditions of the Creative Commons Attribution (CC BY) license (http://creativecommons.org/licenses/by/4.0/). 